IZA DP No. 4282

\title{
Competing on Good Politicians
}

Vincenzo Galasso

Tommaso Nannicini

July 2009 


\title{
Competing on Good Politicians
}

\author{
Vincenzo Galasso \\ Bocconi University, \\ IGIER and CEPR \\ Tommaso Nannicini \\ Bocconi University, \\ IGIER and IZA
}
Discussion Paper No. 4282
July 2009

\author{
IZA \\ P.O. Box 7240 \\ 53072 Bonn \\ Germany \\ Phone: +49-228-3894-0 \\ Fax: +49-228-3894-180 \\ E-mail: iza@iza.org
}

\begin{abstract}
Any opinions expressed here are those of the author(s) and not those of IZA. Research published in this series may include views on policy, but the institute itself takes no institutional policy positions.

The Institute for the Study of Labor (IZA) in Bonn is a local and virtual international research center and a place of communication between science, politics and business. IZA is an independent nonprofit organization supported by Deutsche Post Foundation. The center is associated with the University of Bonn and offers a stimulating research environment through its international network, workshops and conferences, data service, project support, research visits and doctoral program. IZA engages in (i) original and internationally competitive research in all fields of labor economics, (ii) development of policy concepts, and (iii) dissemination of research results and concepts to the interested public.
\end{abstract}

IZA Discussion Papers often represent preliminary work and are circulated to encourage discussion. Citation of such a paper should account for its provisional character. A revised version may be available directly from the author. 


\section{ABSTRACT}

\section{Competing on Good Politicians ${ }^{*}$}

Is electoral competition good for political selection? To address this issue, we introduce a theoretical model in which ideological parties select candidates between party loyalists and experts, and allocate them into the electoral districts. Non-ideological voters, who care about national and local policies, strongly prefer experts. We show that parties compete on good politicians by allocating them to the most contestable districts. Empirical evidence on Italian members of parliament confirms this prediction. We find that politicians with higher ex-ante quality - as measured by years of schooling, previous market income, and local government experience - are more likely to run in a contestable district. Indeed, despite being different on average, the characteristics of politicians belonging to opposite parties converge to highquality levels in close races. Furthermore, politicians elected in contestable districts make fewer absences in parliament; this is shown to be driven more by a selection effect than by reelection incentives.

\section{JEL Classification: D72, H0O}

Keywords: political competition, political selection, probabilistic voting

Corresponding author:

Tommaso Nannicini

Bocconi University

Department of Economics

Via Rontgen, 1

20136 Milan

Italy

E-mail: tommaso.nannicini@unibocconi.it

\footnotetext{
* We thank Alberto Alesina, Tim Besley, Gerard Padro i Miquel, Ernesto Dal Bo, and seminar participants at UC Berkeley, MPSA 2009 Chicago, IGIER, and IMT Lucca for their insightful comments. We are also grateful to "ERE Empirical Research in Economics" for providing the dataset on the Italian members of parliament. Errors are ours and follow a random walk.
} 


\section{Introduction}

In politics, personal identity matters. A lot. Would the UK have had a season of privatization without the leading role of Margareth Thatcher, or the US a New Deal without Franklin Delano Roosevelt? How crucial was Fidel Castro in Cuba's recent history? And what would have happened to the US had Bob Kennedy become its 37th president? A recent literature has recognized the crucial relevance of the identity of leading politicians in taking policy decisions and ultimately in shaping the development of the entire nation (e.g., see Jones and Olken, 2005). ${ }^{1}$ Similar considerations on the crucial role played by some leading persons (that is, CEOs) apply also to the business sector (e.g., see Bertrand and Schoar, 2003).

If identity matters, selecting good politicians becomes ever more crucial. But how to achieve an efficient process of political recruitment? In this paper, we examine the effect of political competition on the selection and allocation of political candidates across electoral districts featuring different degrees of contestability. Competition for electoral support by the voters requires the parties running for election to accurately select their political candidates into districts in order to improve their chances of winning the election. Were thus Stigler (1972) and Wittman (1989) right in claiming that competition is good also for politics? Should we be even more bold in arguing that the dividend of political competition arises from the selection of better politicians?

To address these questions, we introduce a model of political selection in a majoritarian system. The novelty of the model is to allow for a clear role of the party (leaders) in selecting political candidates and allocating them to different electoral districts. Rather than analyzing the self-selection of political candidates - and thus the supply of politicians, as most of the political economy literature - we concentrate on the demand of politicians by parties (leaders). Potential candidates differ ex ante in their identity, namely in their quality type and party loyalty. Quality is perfectly observable by the voters, and good (that is, high-quality) politicians are favorably valued by all non-ideological voters. Parties will therefore have to compete on good politicians. Political competition is captured by the degree of contestability of each electoral district. As in Besley and Preston (2007), the electoral competition at the district level depends on the relative share of aligned and swing voters. More swing voters and

\footnotetext{
${ }^{1}$ See Besley (2005) for a general perspective on the economic analysis of political selection.
} 
a more equal share of the voters aligned to the two parties increase the electoral contestability of a district. An original feature of our model is to allow the parties to target specific districts by allocating a particular type of candidate. Furthermore, unlike most existing work in the literature, we focus on the effect of political competition on the primal party decision, that is, the selection and allocation of politicians, rather than on the policy choice. Our theoretical model predicts that electoral competition has beneficial effects, since parties choose to send their high-quality politicians to the most contestable districts.

To test this prediction, we use a recent dataset on all Italian members of parliament elected in majoritarian (single-member) districts from 1994 to 2006. In that period, Italy represented the perfect testing ground of our theoretical model for several reasons. First, parties (leaders) played a crucial role in the recruitment of political candidates. Second, a majoritarian system was used to elect one of the largest assemblies in the world. Third, for historical reasons, there was a lot of geographic variation in the ideological strongholds of the two major political coalitions (center-right versus center-left). All of these features provide a considerable amount of within-country variation in the degree of political contestability. We use this variation as a treatment and evaluate its effect on political selection.

In particular, to measure the degree of political contestability of a single electoral district, we construct two different indicators: (i) the margin of victory in the previous political election; and (ii) the district-specific ratio of the number of swing voters over the difference between the ideological voters of the two main coalitions. The latter indicator is estimated using electoral data from the previous European elections, which take place under a proportional system and are largely believed to capture ideological voting.

Ex-ante quality by the politicians is instead captured by different measures, such as years of schooling, previous market income, and past experience in local governments. The rationale for each measure is simple. Years of schooling capture the acquisition of formal human capital and skills. ${ }^{2}$ Preelection income, controlling for the occupational type, is a measure of market success and ability. The use of administrative experience is linked to the idea that lower-level elections can be used by high-quality politicians to build reputation

\footnotetext{
${ }^{2}$ Besley and Reynal-Querol (2009) use the same measure to assess political selection in democracy versus autocracy. Zhang and Congleton (2008) find a positive correlation between the educational level of US Presidents and aggregate economic outcomes.
} 
and by voters to screen better candidates. ${ }^{3}$ Consistently with our theoretical framework, we find evidence of an ex-ante selection effect of political competition: politicians with more years of schooling, higher preelection income, and more local experiences tend to be allocated to contestable (nonsafe) districts. Interestingly, although the two main political coalitions show very different patters of political selection (with the center-right coalition recruiting politicians with higher education, and the center-left selecting more women and politicians with previous administrative experience), evidence from a regression discontinuity design shows that both parties converge to the same high-quality type in close races. In other words, only when the going gets tough, the tough candidates get the job from their parties.

To capture ex-post quality by the elected officials, we consider the absenteeism rate in electronic parliament votes, which we consider a proxy for shirking or rent-seeking. ${ }^{4}$ Our empirical evidence shows that politicians elected in contestable districts display a lower absenteeism rate. This is consistent with the selection of better politicians in those districts, but may also be driven by reelection incentives. To disentangle the two channels, we exploit some (exogenous) changes in political alliances forced by national leaders, which had the effect of altering the degree of contestability of certain districts from one election to the next. ${ }^{5}$ Interestingly, we find that the effect of political selection strongly dominates, because the ex-ante contestability of the district has a sizable impact on performance even if we control for the altered reelection incentives. An incentive effect does however exist, particularly for low-quality politicians, as we find that, when a safe district turns contestable, low-quality incumbent politicians tend to exert more effort.

Our results on Italy point to the existence of a selection dividend of political competition, which can be extended to countries with a majoritarian electoral rule and strong parties, such as the UK. Moreover, we expect the same positive association between the ex-ante quality of politicians and political competition to hold even in majoritarian environments with a weak party structure, such as the US. For example, this will occur if primary voters

\footnotetext{
${ }^{3}$ On this point, from a theoretical perspective, see Cooter (2002) and Myerson (2006).

${ }^{4}$ For instance, Gagliarducci, Nannicini, and Naticchioni (2008) show that the absenteeism rate is positively associated with the amount of outside income by members of parliament.

${ }^{5}$ The instability of the party system during the period that followed the judiciary scandals known as "Mani pulite" (1992-94) and the switch from a proportional to a majoritarian electoral rule in 1994, produced national changes in political alliances both in the right-wing and left-wing coalitions, which exogenously affected the contestability of a few districts in different elections. See Section 4.2 for a discussion.
} 
selecting their party's candidate trade off ideological loyalty for better skills, in order to attract independent voters in the true election. More generally, whenever non-aligned voters care about the personal attributes of candidates and the electoral race is tight, we expect competition on good politicians. Therefore, from a normative perspective, our findings call for institutions and policies able to: i) increase voters' information and awareness about the quality of political candidates; and ii) enhance the degree of contestability of electoral races.

The paper proceeds as follows. Section 2 provides a review of the related literature. Section 3 introduces our theoretical framework and derives the main results regarding the selection of candidates into the electoral districts. Section 4 describes the data and the institutional framework, while the estimation strategy and the empirical results are presented in section 5. Finally, section 6 concludes. Proofs are in the Appendix.

\section{Related Literature}

Our paper is related to several strands of literature. Our theoretical framework shares some features with the models introduced by Alesina (1988) and Besley and Preston (2007). Two ideological parties compete for the votes of aligned (or committed) voters and of swing voters. However, as in Alesina (1988), parties' platforms need not to converge. The degree of political competition depends on the distribution of swing and aligned voters into electoral districts. ${ }^{6}$ Yet, while in Besley and Preston (2007) parties choose an economy-wide policy and are unable to target specific districts, our novelty is to assign to the parties the primal roles of selecting candidates and allocating them into the electoral districts. This allocation decision is crucial in our setting, as it allows the parties to target specific districts. The importance of district-specific policies to win the election has been carefully evaluated by Stromberg (2008), who examined the distribution of visits to the different US states by presidential candidates. ${ }^{7}$

In our framework, parties select politicians according to their identity. As in Besley (2005), candidates differ in their quality, that is, in their ability or expertise in problem

\footnotetext{
${ }^{6}$ In the literature on the estimation of seat-vote curves, Coate and Knight (2007) use a similar model with a distribution of democrats, republicans, and independents across districts to examine optimal districting.

${ }^{7}$ Persico, Rodriguez-Pueblita, and Silverman (2008) examine how parties that are internally divided into factions determine the allocation of pork spending. To the extent that internal factions occur along geographical lines, their results have implications for geographical targeting. Persson and Tabellini (2000), Lizzeri and Persico (2001), and Milesi-Ferretti, Perotti, and Rostagno (2002) study the political incentives for policies targeted at specific districts under alternative electoral rules (that is, proportional versus majoritarian).
} 
solving. This feature is valued by the non-ideological voters, and hence by the political parties seeking to win the election. Our model of political selection concentrates in fact on the choice of political candidates by the party. This demand for politicians has largely been neglected in the literature, despite the predominant role played by (strong) political parties in most of contemporaneous democracies. A notable exception is represented by Carrillo and Mariotti (2001), who analyze the party decision between an experienced, and thus known, incumbent and a new candidate of uncertain quality. In an asymmetric information setting, they show that parties may have an incentive to confirm mediocre incumbents. Mattozzi and Merlo (2006) focus instead on the competition between parties and lobbying firms in hiring political candidates. In their framework, parties may find it optimal to attract low-quality politicians, the best individuals being out of reach.

There exists instead a recent and growing literature on the supply (or self-selection) of politicians (see Besley, 2005, for a review). Following the tradition of the citizen-candidate framework (Besley and Coate, 1997; Osborne and Slivinski, 1996), this literature has analyzed the determinants that bring individuals to enter the political market and to compete for election. A common theme has thus been how to attract good politicians. Models that predict adverse selection in politics (Besley, 2004; Caselli and Morelli, 2004) are based on the assumption that the private and political sectors are mutually exclusive, and therefore lowquality individuals have a lower opportunity cost of running for office. ${ }^{8}$ Mattozzi and Merlo (2008) emphasize the role of the public office in signaling ability. In their framework, some high-ability citizens decide to serve for a short period, after which they leave parliament and capitalize on their political experience (see also Diermeier, Keane, and Merlo, 2005). Gagliarducci, Nannicini, and Naticchioni (2008) suggest that allowing for outside income while in parliament may lead to positive sorting. Finally, Dal Bo and Di Tella (2003) and Dal Bo, Dal Bo, and Di Tella (2006) suggest that, besides monetary compensations or bribes, self-selection can also be affected by threats and violence. Also recent empirical studies have investigated the effect of monetary incentives on politicians' self-selection. Gagliarducci and Nannicini (2008) and Ferraz and Finan (2008) use a quasi-experimental setup and find that a higher remuneration attracts more skilled individuals into politics, enhancing both political

\footnotetext{
${ }^{8}$ Messner and Polborn (2004) also predict negative sorting, although in their case the rationale for adverse selection is that high-quality citizens free-ride on low-quality ones, because for the former the attractiveness of the public office is low. See also Poutvaara and Takalo (2007) on the same issues.
} 
selection and performance. However, using data on Italian members of parliament, Merlo et al. (2009) show a negative association over time between the parliament salary and politicians' quality (as measured for instance by educational attainments).

A recent literature examines the effect of political competition on policy outcomes. Besley, Persson, and Sturm (2008) use different measures of the degree of political competition in US local elections, and find evidence of a positive effect of competition on growth enhancing policies and, ultimately, on economic growth. Stromberg (2008) analyzes how US presidential candidates allocate resources across states to maximize their probability of winning the election, and shows that this allocation is affected by the number of electoral votes and forecast uncertainty. Dal Bo, Dal Bo, and Snyder (2009) show that political dynasties (that is, intergenerational transmission of political power and elected offices) are less likely to emerge in competitive environments. Lizzeri and Persico (2005) argue instead that more electoral competition, defined as lower barriers to entry in the party system, may increase the number of competing political parties and lead to inefficient special-interest policies.

\section{The Model}

Our model describes the allocation of political candidates into electoral districts by two parties that compete in a majoritarian election. Parties have different preferences over a national policy, $Y$. Since policies are set by the winning party, parties (leaders) seek to win the election, in order to implement a suitable policy. Before the election, parties have to allocate their candidates in the districts. Candidates can be loyalists - to the partyor experts. Loyalists provide party services, while experts are better equipped at problem solving, but less willing to follow the party lines. Voters care about national and local policies. They can be of three types: supporters of either party or centrist, that is, not aligned to any party. We embed the voting decision of the centrist voters in a standard probabilistic voting model (see Lindbeck and Weibull, 1987). Since centrist voters strongly prefer to have experts in their districts, the decision of where to allocate the candidates carries important implications for winning the election. 


\subsection{The Set-up}

We consider two parties, $L$ and $R$, which derive utility from a national policy, $Y$. Their preferences are represented respectively by $V_{L}(Y)$ and $V_{R}(Y)$. Since parties have different preferences, their bliss point over the national policy will also differ, $\widehat{Y}_{L} \neq \widehat{Y}_{R}$. It is useful, albeit not crucial, to consider that this national policy may depend on the share of experts and loyalists in the party list, i.e., $Y_{i}=Y_{i}(\mu)$, where $\mu$ represents the share of experts in the party list. The main role of the party (leaders) before the election is to allocate the candidates into the electoral districts. After the election, the winning party sets the national policy, $Y$, and each winning candidate provides constituency service for its district.

Candidates can be of two types: loyalists $(L)$ or experts $(E)$. Loyalists exert most of their effort to provide party services or rents, and are under the party direct control. Experts, on the other hand, are problem solvers; they may also be (relatively) loyal to the party, but they provide fewer party services, since their effort is predominantly targeted at other policies.

We consider three groups of voters. Voters in group $L$ and $R$ are core supporters and always vote for party $L$ and $R$, respectively. Voters in group $C$ care instead about the national and local policy, that is, in their electoral district. Hence, political candidates play a double role for the voters. Besides affecting the national policy, $Y(\mu)$, they provide constituency service, for instance by bringing the attention of the national government to local instances that affect their district. The utility that group $C$ voters living in district $k$ derive from the policy selected by party $i$ and candidate $j$ is summarized by the following expression:

$$
U_{C}^{k}\left(Y_{i}, z_{j}^{k}\right)=(1-\rho) V_{C}\left(Y_{i}\right)+\rho V_{C}\left(z_{j}^{k}\right)
$$

where $Y_{i}$ is party- $i$ national policy, $z_{j}^{k}$ is candidate- $j$ policy in district $k$, and $\rho$ measures the relative importance to the voters of the local versus the national policy. To further characterize these preferences, without loss of generality, we assume that when the two parties select the same share of experts, their national policies provide the same utility to these $C$ voters. That is, $V_{C}\left(Y_{L}\left(\mu_{L}\right)\right)=V_{C}\left(Y_{R}\left(\mu_{R}\right)\right)$ for $\mu_{L}=\mu_{R}$, although $Y_{L}\left(\mu_{L}\right) \neq Y_{R}\left(\mu_{R}\right) .^{9}$ Moreover, these voters' utility from the national policy is increasing in the share of experts, $\partial V_{C}\left(Y_{i}\left(\mu_{i}\right)\right) / \partial \mu_{i}>0$.

\footnotetext{
${ }^{9}$ This property can easily be derived in an environment in which the two parties have a symmetric bias in their preferences over $Y$ with respect to the centrist voters (see Galasso and Nannicini, 2009).
} 
At the local level, centrist voters prefer to have expert candidates in their districts. In fact, we assume that $V_{C}\left(E_{L}\right)=V_{C}\left(E_{R}\right)>V_{C}\left(L_{L}\right)=V_{C}\left(L_{R}\right)$, where $E_{i}$ and $L_{i}$ represent, respectively, the policy chosen at the local level by a party- $i$ expert and loyalist.

Finally, according to the probabilistic voting approach, we assume that these voters may feel ideologically closer to one party or another. The ideological characteristic of each centrist voter is indexed by $s$, with $s>0$ if the voter is closer to party $R$, and vice versa. The distribution of ideology among centrist voters is assumed to be uniform. In particular, to simplify the notation, we consider $s \sim U[-1 / 2,1 / 2]$. The centrist voters' decision is also affected by a common popularity shock to the parties, which occurs before the election and may modify the perception, $\delta$, that all centrist voters have about the image of the two parties. In particular, if $\delta>0$, party $R$ gains popularity from this pre-electoral image shock and vice versa for $\delta<0$. Again, as it is customary in this class of probabilistic voting models, we assume that $\delta$ is uniformly distributed, so that $\delta \sim U\left[-\frac{1}{2 \psi}, \frac{1}{2 \psi}\right]$ with $\psi>0$.

To summarize, a centrist voter will support party $L$ if the utility obtained by the (national and local) policy adopted by party $L$ is larger than the sum of the ideological idiosyncratic component, $s$, of the common shock, $\delta$, and of the utility obtained by party $R$. That is, a centrist in district $k$ prefers party $L$ if $U_{C}^{k}\left(Y_{L}, z_{L}^{k}\right)-U_{C}^{k}\left(Y_{R}, z_{R}^{k}\right)-s-\delta>0$.

\subsection{Voters and Districts}

The incentives for the parties to allocate their candidates in the different districts depend largely on the behavior of the centrist voters. In fact, given its preferred national policy, or equivalently the share of experts and loyalists in the party list, a party needs to win the election in order to be able to set up the actual policy. Ultimately, parties need to convince the centrist voters by competing on good politicians.

The distribution of the three groups of voters in the electoral districts determines the districts where the electoral race is tight, and those where instead one of the two parties has a substantial advantage. Call $\lambda_{k}^{j}$ the share of type- $j$ voters in district $k$ with $j=\{L, C, R\}$. We assume that the share of type- $C$ (centrist) voters is constant across district, that is, $\lambda_{k}^{C}=\lambda^{C} \forall k$. It is convenient to define our measure of ex-ante contestability of every district $k$ as

$$
\lambda_{k}=\frac{1}{2} \frac{\lambda_{k}^{R}-\lambda_{k}^{L}}{\lambda^{C}}
$$


When parties $L$ and $R$ have an equal share of aligned voters in the district - and hence there is maximum electoral contestability - this index is equal to zero, $\lambda_{k}=0$; while higher (positive) and lower (negative) values indicate less contestability. Moreover, it is easy to see that party $L$ always wins in those districts with $\lambda_{k}<-1 / 2$, in which group- $L$ voters represent a majority of the electorate; while party $R$ always prevails in districts with $\lambda_{k}>1 / 2$. Hence, only districts with intermediate values of $\lambda_{k} \in[-1 / 2,1 / 2]$ are contestable. To characterize the distribution of voters' type across districts, we consider a continuum of districts, characterized by a degree of contestability, $\lambda_{k}$, that is uniformly distributed around $\lambda_{k}=0$, with a support $\lambda_{k} \in\left[-\frac{1-\lambda^{C}}{2 \lambda^{C}}, \frac{1-\lambda^{C}}{2 \lambda^{C}}\right]$. We refer to the cumulative distribution as $G\left(\lambda_{k}\right)$.

We are now in the position to assess the probability that a party - e.g., party $L$ - wins a contestable district $k$. Call $\widetilde{s}$ the ideology of the swing voter, that is, of the centrist voter who is indifferent between party $L$ or $R$. Hence, $\widetilde{s}=U_{C}^{k}\left(Y_{L}, z_{L}^{k}\right)-U_{C}^{k}\left(Y_{R}, z_{R}^{k}\right)-\delta$, and all centrist voters with ideology $s<\widetilde{s}$ will support party $L$. To win district $k$, the sum of type- $L$ voters $\left(\lambda_{k}^{L}\right)$ and of the votes that party $L$ obtains from the centrist voters has to exceed $50 \%$. It is easy to see that this occurs for $\widetilde{s}>\lambda_{k}$. Thus, the probability of party $L$ winning district $k$ - call it $\Pi_{L}^{k}$ - can be expressed as a function of the popularity shock, $\delta$, and of the district characteristic, $\lambda_{k}$ :

$$
\Pi_{L}^{k}=\operatorname{Pr}\left\{\delta<U_{C}^{k}\left(Y_{L}, z_{L}^{k}\right)-U_{C}^{k}\left(Y_{R}, z_{R}^{k}\right)-\lambda_{k}=d_{k}\right\}
$$

where $d_{k}$ can be interpreted as a measure of the ex-post contestability of district $k$, that is, after that the parties' national policy and allocation of candidates are known to the voters. Since the popularity shock is uniformly distributed with density $\psi$, we can rewrite equation 3 as $\Pi_{L}^{k}=\frac{1}{2}+\psi d_{k}$. If the two parties converge to the same allocation of candidates, and to national policies that provide the same utility to the centrist voters, then $d_{k}=-\lambda_{k}$. However, parties can use the allocation of candidates to modify $d_{k}$, and thus their chance of winning any district $k$.

\subsection{Allocation of Candidates}

To understand the choice of the allocation of candidates into districts, it is convenient to summarize the timing of events. Parties move first. Before the election, they choose how to allocate their loyal and expert candidates into the different electoral districts. The share of 
loyalists and experts in each party $\left(\mu_{L}, \mu_{R}\right)$ is taken as given, and also the national policies $\left(Y_{L}, Y_{R}\right)$ are assumed to be exogenous. ${ }^{10}$ The two parties take their allocation decision independently and simultaneously; they know the distribution of the popularity shock taking place before the election, but not its realization. After the popularity shock has occurred, centrist voters decide who to support between the two candidates running in their electoral district. Centrist voters care about national and local policies. After the election, the winning party determines the national policy and the winning candidate chooses the local policy.

Parties are entitled to set the national policy only if they win the election. Hence, they will use their allocation decision in order to maximize the expected utility (for party $L$ ):

$$
\Pi_{L} V_{L}\left(Y_{L}\right)+\left(1-\Pi_{L}\right) V_{L}\left(Y_{R}\right)
$$

where $\Pi_{L}$ represents party- $L$ probability of winning the election and $V_{L}\left(Y_{i}\right)$ is party- $L$ utility when the national policy is selected by party $i$. Since $Y_{L}$ and $Y_{R}$ are given, and $V_{L}\left(Y_{L}\right)>$ $V_{L}\left(Y_{R}\right)$, party $L$ will seek to maximize its probability of winning the election, $\Pi_{L}$; and analogously for party $R$.

With a fixed share of experts for parties $L$ and $R$, respectively $\mu_{L}$ and $\mu_{R}$, and given the national policies $Y_{L}$ and $Y_{R}$ - possibly determined by these shares- parties compete by allocating experts to the crucial districts. The difference in utility provided to the centrist voters in district $k$ by the two parties can be written as

$$
U_{C}^{k}\left(Y_{L}, z_{L}^{k}\right)-U_{C}^{k}\left(Y_{R}, z_{R}^{k}\right)=(1-\rho) D+\rho\left(V_{C}\left(z_{L}^{k}\right)-V_{C}\left(z_{R}^{k}\right)\right)
$$

where $D=V_{C}\left(Y_{L}\right)-V_{C}\left(Y_{R}\right)$ is exogenous, and depends on the given national policies. It simplifies the analysis to consider that both parties have the same share of experts to allocate, $\mu=\mu_{L}=\mu_{R}$, and therefore $D=0 .{ }^{11}$

As experts are more valuable than loyalists to the centrist voters, allocating an expert to a district $k$, where the other party sent a loyalist, amounts to increase their utility by a positive wedge, $W=\rho\left[V_{C}(E)-V_{C}(L)\right]$. More centrist voters in that district will then

\footnotetext{
${ }^{10}$ In Galasso and Nannicini (2009), we endogenize the selection of candidates in a majoritarian (and proportional) system. Selecting the share of experts to be allocated introduces an additional trade-off for the party. More experts lead to policies that are closer to the swing voters and hence increase the party's probability of winning the election; but more loyalists implement policies that are closer to the party's bliss point.

${ }^{11}$ In Galasso and Nannicini (2009), we show that this arises as an equilibrium property of the political selection decision.
} 
favor party $L$. Hence, parties compete on good politicians (the experts) to increase their probability of winning a contestable district.

To understand the logic behind this simultaneous allocation game, suppose that only loyal candidates have been sent to districts, and are thus perfectly matched, that is, every party- $L$ loyalist faces a party- $R$ loyalist. This implies that $V_{C}\left(z_{L}^{k}\right)-V_{C}\left(z_{R}^{k}\right)=V_{C}(L)-V_{C}(L)=0$. By equation 3, party $L$ thus wins a district $k$ if $\delta<d_{k}=-\lambda_{k}$. Moreover, given the distribution of districts $\left(\lambda_{k}\right)$, party $L$ wins the elections - that is, it obtains more than $50 \%$ of the districts - if $\delta<d_{0}=0$. In this case, party $L$ wins all the districts with $\lambda_{k}<0$, as shown in Figure 1; whereas it ties the election for $\delta=d_{0}=0$. Thus, the marginal (or pivotal) districts to win are in a small interval around $\lambda_{k}=0$ (henceforth, $\lambda_{0}$ ). It is convenient to represent an interval around $\lambda_{0}$ as $\left[\lambda_{\varepsilon}, \lambda_{\Xi}\right]$, with $\lambda_{0}-\lambda_{\varepsilon}=\lambda_{\Xi}-\lambda_{0}=\varepsilon$ small enough.

Suppose now that party $L$ sends experts to the district interval $\left[\lambda_{0}, \lambda_{\Xi}\right]$. Using again equation 3 , it is easy to see that party $L$ will now be more likely to win those districts. In fact, party $L$ will win district $\lambda_{0}$ even for a worse (i.e., larger) realization of the shock, that is, for $\delta<W$. Define the district $\lambda_{w}=-W$, such that $d_{w}=W$. Then, if party $L$ allocates an expert to the most contestable district, $\lambda_{0}$, where party $R$ has instead sent a loyalist, party $L$ will win this district with a probability which is the same as the probability of winning district $\lambda_{w}<0$ (which is biased in favor of party $L$ ) when both parties send there a loyalist. Hence, with experts in the district interval $\left[\lambda_{0}, \lambda_{\Xi}\right]$, party $L$ would win the election for $\delta=d_{0}=0$, rather than just tying it (see Figure 2). And analogously for party $R$ in the interval $\left[\lambda_{\epsilon}, \lambda_{0}\right]$. Also for party $R$ we can define a district $\lambda_{W}=W$ with $d_{W}=-W$, so that if party $R$ allocates an expert to $\lambda_{0}$ and party $L$ a loyalist, the probability of winning in $\lambda_{0}$ is equal to the probability of winning in $\lambda_{W}$ (when both parties send there a loyalist).

Districts $\lambda_{w}$ and $\lambda_{W}$ represent crucial thresholds, respectively for party $L$ and $R$. To see this, suppose that party $R$ only allocates loyalists; then party $L$ would maximize its probability of winning the election by sending experts to all districts between $\lambda_{w}$ and $\lambda_{\Xi}$. In this case, party $L$ would win the election if $\delta \leq d_{w}=-\lambda_{w}$; and allocating an additional expert in any district would not modify this probability. It is convenient to define the mass of districts included between $\lambda_{w}$ and $\lambda_{0}$ as $\eta / 2$; that is, $\left[G\left(\lambda_{0}\right)-G\left(\lambda_{w}\right)\right]=\eta / 2$. Then, $\eta / 2$ experts would be needed by party $L$ to span the districts between $\lambda_{w}$ and $\lambda_{0}$. The same logic 
applies to party $R$, with the threshold district being $\lambda_{W}$, and $\left[G\left(\lambda_{W}\right)-G\left(\lambda_{0}\right)\right]=\eta / 2 .{ }^{12}$

Before turning to the next proposition, which characterizes the equilibrium allocation of candidates, it is convenient to introduce some definitions. Define $\Lambda^{L}$, party- $L$ allocation of experts, as the union of the district intervals $\Lambda_{i}^{L}=\left[\lambda_{I}^{i}, \lambda_{I I}^{i}\right]$ where party $L$ allocates its experts, $\Lambda^{L}=\cup_{i} \Lambda_{i}^{L}$, and analogously $\Lambda^{R}$ for party $R$.

Proposition 1. Parties allocate experts in district intervals that include the most contestable district $\lambda_{0}$.

(I) For $\mu>\eta / 2$, party $L$ allocation of experts $\Lambda^{L}$ includes $\Lambda_{i}^{L}=\left[\lambda_{I}^{i}, \lambda_{I I}^{i}\right]$ with $\lambda_{I}^{i}<\lambda_{w}$ and $\lambda_{I I}^{i}>\lambda_{\Xi}$; and party $R$ allocation $\Lambda^{R}$ includes $\Lambda_{i}^{R}=\left[\lambda_{I}^{i}, \lambda_{I I}^{i}\right]$ with $\lambda_{I}^{i}<\lambda_{\varepsilon}$ and $\lambda_{I I}^{i}>\lambda_{W}$

(II) For $\mu \leq \eta / 2$, party $L$ allocation of experts is $\Lambda^{L}=\left[\lambda_{0}, \lambda_{B}\right]$, such that $G\left(\lambda_{B}\right)=1 / 2+\mu$, and party $R$ allocation is $\Lambda^{R}=\left[\lambda_{b}, \lambda_{0}\right]$, such that $G\left(\lambda_{b}\right)=1 / 2-\mu$.

Proof. See Appendix.

In words, as previously argued, allocation matters in the districts $\left[\lambda_{w}, \lambda_{\Xi}\right]$ for party $L$, and $\left[\lambda_{\varepsilon}, \lambda_{W}\right]$ for party $R$, where sending an expert may actually change the probability of winning the election. For $\mu>\eta / 2$, having enough experts, both parties will hence send them to cover these critical districts. The allocation of additional experts does not affect the probability of winning the election, although it modifies the share of seats obtained by the party. When parties are instead supply constrained in the share of experts, $\mu<\eta / 2$, the allocation strategy changes radically. Rather than concentrating their experts on a subset of the districts that are in their favor, parties prefer to use their few experts to try to win the districts that are (weakly) in favor of the other party.

The bottom panels of Figures 3 through 5 provide a graphical representation of equilibrium allocations described in the proposition above. Figure 3 displays a case in which parties have many experts $(\mu>\eta / 2)$ and match candidates' type in every district (see bottom panel). The probability of winning a district $k$ only depends on its idiosyncratic characteristic, $\lambda_{k}$

\footnotetext{
${ }^{12}$ Notice that the mass of crucial districts between $\lambda_{w}$ and $\lambda_{W}$ is equal to $\eta=\frac{2 \lambda^{C}}{1-\lambda^{C}} \rho\left(V_{C}(E)-V_{C}(L)\right)$. The share of experts needed to cover all of them thus depends positively on the proportion of centrist voters $\left(\lambda^{C}\right)$, on the relative importance of the local policy $(\rho)$, and on the value of an expert in the district.
} 
(see top panel). Figure 4 (bottom panel) presents instead a symmetric equilibrium allocation (still for $\mu>\eta / 2$ ) in which parties span their experts on the relevant contestable districts biased in their favor, and send additional experts to the districts that are more favorable to the opposing party. The top panel shows how the resulting probability of winning a district is higher for the party whose expert faces a loyalist from the opposing party. In both cases, parties always allocate experts around the most contestable district, that is, party $L$ in $\left[\lambda_{w}, \lambda_{\Xi}\right]$ and party $R$ in $\left[\lambda_{\varepsilon}, \lambda_{W}\right]$.

With fewer experts to spare $(\mu<\eta / 2)$, parties have to modify their allocation strategy. In particular, party $L$ will send experts to districts $\lambda_{k} \in\left[\lambda_{0}, \lambda_{B}\right]$, as shown in Figure 5 (bottom panel). The intuition is the following. With only a few experts to allocate, party $L$ could still secure the favorable districts close to the pivotal one (as in the previous strategies), but it would have to send loyalists to the other more favorable, albeit still contestable, districts. This would leave them open to the competition by party $R$, which would have an incentive to send there its experts, thereby turning these districts into its favor. Instead of using this (losing) defensive strategy, party $L$ will prefer to allocate its experts to the districts close to the pivotal $\left(\lambda_{0}\right)$, which favor its opponent. And analogously for party $R$. Figure 5 (top panel) shows how this offensive strategy turns some of the districts originally close to party $R$ (namely, those between $\lambda_{0}$ and $\lambda_{B}$ ) in favor of party $L$, and vice versa for the districts between $\lambda_{b}$ and $\lambda_{0}$.

The results in Proposition 1 suggest that to increase the probability of winning the election, parties (leaders) allocate their expert candidates close to the most contestable district, $\lambda_{0}$. The next corollary shows that this allocation strategy translates into more experts being elected in contestable districts than elsewhere.

Corollary 1. The share of experts elected in the interval $\left[\lambda_{\varepsilon}, \lambda_{\Xi}\right]$ around the most contestable district, $\lambda_{0}$, is (weakly) larger than the share of experts elected in $\left[\lambda, \lambda_{\varepsilon}\right] \cup\left[\lambda_{\Xi},-\lambda\right], \forall \lambda<\lambda_{\varepsilon}$, and thereby than the overall share of elected experts.

Proof. See Appendix.

To see this, consider the case of many experts $(\mu>\eta / 2)$, where both parties send them to the most contestable district interval $\left[\lambda_{\varepsilon}, \lambda_{\Xi}\right]$. Only experts are hence elected in that interval, regardless of the realization of the popularity shock. With fewer experts $(\mu<\eta / 2)$, again 
only experts would win in $\left[\lambda_{\varepsilon}, \lambda_{\Xi}\right]$ for small realizations of the shock $d_{W}<\delta<d_{w}$; but for larger shocks only the winning part would elect experts (see Figure 5). The share of experts in $\left[\lambda_{\varepsilon}, \lambda_{\Xi}\right]$ would then be $1 / 2$, which is still greater than the overall share of elected experts, as long as the fraction of crucial districts $(\eta)$ is lower than one.

\section{The Data}

\subsection{Institutional Setup and Data Sources}

In order to test the main empirical implications of the theoretical model presented in the previous section, we use data about the members of the Italian parliament (House of Representatives and Senate) from 1994 to 2006, which refer to legislative terms XII (1994-96), XIII (1996-2001), and XIV (2001-06). ${ }^{13}$ During this period, Italy had a two-tier electoral system (75\% majoritarian and $25 \%$ proportional). In the majoritarian tier, members of parliament were elected in single-member districts with plurality voting. In the proportional tier, they were selected from closed party lists at the regional level (House) or from the best losers in the majoritarian districts (Senate). Following the breakdown of the old party system and the electoral reform in 1994, the political arena figured two major coalitions, center-right and center-left: the former won the election in 1994 and 2001, and the latter in 1996.

Italy represents the ideal ground for evaluating the impact of political competition on political selection, because of some peculiar features of its institutional and political framework, such as: 1) the majoritarian electoral system in place from 1994 to 2006; 2) one of the largest legislative assemblies in the world (945 members of parliament against, for instance, 535 in the US or 575 in France); 3) a great deal of geographic variation in the ideological strongholds of the center-right and center-left coalitions. These features provide a considerable amount of within-country variation in the degree of political contestability of the electoral districts, which allows us to test the theoretical prediction at Corollary 1.

The dataset contains the following information on each member of parliament: demographic characteristics (age, gender, marital status, number of children, level and field of

\footnotetext{
${ }^{13}$ For more information on the dataset, see Gagliarducci, Nannicini, and Naticchioni (2008). The original sources used to collect the data include: the Annals of the Italian Parliament (La Navicella) for demographic information, as well as professional and political experience; the Archive of Tax Returns of the members of the Italian Parliament (Servizio Prerogative e Immunità) for income information; and the Italian Parliament Press Office (Ufficio Stampa) for data on individual attendance at voting sessions.
} 
education); self-declared previous job (before entering parliament for the first time); absenteeism rate (the share of electronic votes missed without any legitimate reason); parliament appointments (president, vice president, and secretary either of the parliament or of a legislative committee); government appointments (minister, vice minister); party affiliation and political roles (member of the directive board of the party at the local, regional, or national level); local government experience (mayor, city councillor, president of a region, etc.); tier of election, electoral district, and margin of victory.

\subsection{Measuring Political Competition}

We restrict our analysis to politicians elected in majoritarian districts, where we can measure the degree of political contestability, that is, the expected electoral gap between the two major coalitions. There were 705 districts (475 in the House and 230 in the Senate) for each legislative term. Hence, our sample could consist of at most 2,115 observations across the three terms covered by the dataset. After dropping observations with missing values in the relevant variables, we are left with a sample of 1,977 observations for terms XII-XIII-XIV and 1,307 for terms XIII-XIV.

Table 1 shows that, in $25 \%$ of the districts, the center-left coalition won all three elections, while the center-right always won in 34\%. The remaining $40 \%$ swang at least once. Safe (nonswing) districts are particularly concentrated in the North East and Center of the country (see Table 2). The lagged margin of victory in absolute value $(M V)$ is an obvious measure of the ex-ante contestability of the district: for example, if a coalition won by 30 percentage points in the previous election, it will be very difficult for the other coalition to fight back and win the district the next time. By the same token, alternative measures of the safeness of a district could be $M V$ being greater than 5 (Safe1) or greater than 10 (Safe2). The distribution of the margin of victory in each single-member district - expressed in percentage points - is positively skewed. In about $29 \%$ of the districts, the lagged margin of victory was lower than 5, while in about $49 \%$ it was lower than 10 .

All of these measures, based on the lagged margin of victory, should be good predictors of the swinging probability of a district, but their correlation with the characteristics of the individual candidates could be biased when the incumbent runs for reelection. In this case, the lagged margin of victory would refer to an election run by the same politician, and thus 
partly depend on his skills. Furthermore, measures based on the lagged margin of victory are not available for the XII legislative term, because the majoritarian districts were first introduced in this term. To address both issues, we construct an additional measure of contestability by using the district-specific vote shares of different parties at the European elections, held either in 1994 or 1999. We consider as ideological (or loyal) voters those who supported the center-left $(L)$ or center-right coalition $(R)$ in the previous European election. These elections, in fact, were held under proportional representation to appoint the Italian representatives in the European Parliament. Their turnout rate has usually been lower than in national elections, because government decisions are not at stake. Political analysts therefore agree that voters cast a more ideological vote in this type of electoral contest. Our new measure of safeness (Safe3) is then equal to one if

$$
\frac{1-L-R}{|L-R|} \leq 1
$$

This measure can be interpreted as the empirical counterpart of $1 / \lambda_{k}$ in the theoretical model. Furthermore, it has the advantage of allowing us to identify changes in the degree of contestability of a district due to national variations in political alliances, within each coalition. Large modifications occured twice: in 1996 the rightist party Lega Nord quit the center-right coalition because of alleged divergences over government policy; while the leftist party Rifondazione Comunista quit the center-left coalition before the 2001 election. These alliance breakdowns originated from the narrow incentive of the two small parties to keep up their (proportional) vote share and bargaining power, and they developed around struggles between the national leaderships. Their impact on the political future of backbenchers and on the contestability of districts was not internalized. In fact, the breakdowns were decided by the leaders of small parties, while they mainly affected the destiny of the representatives of big parties in marginal districts; moreover, political analysts agree that the breakdowns followed purely proportionalistic motivations and were decided at the top of the party structure. As a result, these national shocks altered the degree of contestability of a few districts in a way that can be interpreted as sufficiently exogenous with respect to the characteristics of politicians previously elected in those districts.

Table 3 shows that all of our measures of ex-ante contestability are correlated with the ex-post probability that a district swings from a coalition to the other. The probability of 
swinging is always higher when our safeness indicators are equal to zero, and the differences are statistically significant either at the 1\% level (Safe1 and Safe2) or at the 5\% level (Safe3). The probability of swinging also increases with the lagged margin of victory.

\subsection{Outcome Variables}

The above measures of political competition represent our treatment of interest. We want to evaluate whether increasing the intensity of such a treatment affects the patterns of political selection. In other words, we want to assess whether political parties allocate candidates with different ex-ante characteristics according to the degree of contestability of the district. Table 4 summarizes the preelection characteristics of the politicians in our sample, according to the contestability of the district where they were elected (as captured by the indicator Safe2). On average, candidates allocated to nonsafe districts are more educated, have lower parliament or government experience but greater local government experience, and declare higher preelection incomes. Physicians tend to run in more contestable districts. Party officers, on the contrary, are allocated to safer districts.

Table 5 summarizes information on the ex-post behaviors and appointments of the members of parliament. Politicians elected in contestable districts tend to work harder in parliament, that is, they display a lower absenteeism rate in electronic votes, both overall and at the end of the legislative term. ${ }^{14}$ It is worth noticing that politicians elected in contestable districts have a higher probability to enter the government (if their coalition wins the general election), although they have lower government experience than politicians running in safe districts (see again Table 4). This is consistent with the view that those candidates are more skilled than the others, and that they are rewarded for winning tougher races.

\section{$5 \quad$ Empirical Results}

\subsection{The Impact of Political Competition on Selection}

To evaluate whether any predetermined characteristic $\left(X_{i j t}\right)$ of politician $i$ in district $j$ at time $t$ is associated with the degree of contestability of the district where he is elected $\left(C_{i j t}\right)$,

\footnotetext{
${ }^{14}$ Only votes missed without any legitimate reason are considered (i.e., parliament missions or cabinet meetings are not counted as absences). Electronic votes account for about $90 \%$ of total floor votes (almost the totality if the vote was on a final bill approval), the rest being held with hand counting.
} 
we implement the following set of regressions (depending on the measure used to capture contestability):

$$
C_{i j t}=\delta_{t}+\gamma_{j}+\beta X_{i j t}+\eta_{i j t}
$$

where regional dummies $\gamma_{j}$ control for geographical factors correlated with both political competition and political selection, $\delta_{t}$ for time fixed effects, and the error terms $\eta_{i j t}$ are clustered at the individual level. If $C_{i j t}$ is a dummy, we estimate a Probit model; if it is continuous, we use OLS. These estimations can be seen as a direct test of Corollary 1, which suggests that experts (defined on the basis of the available observable characteristics discussed in the previous section) are more likely to be elected in contestable districts.

The estimation results are reported in Table 6. To control for the possible endogeneity problem between $C_{i j t}$ and $X_{i j t}$, which arises when $C_{i j t}$ is based on the lagged margin of victory, and thus partly affected by the skills of the incumbent who is now running for reelection, we also restrict the sample to no incumbents only. ${ }^{15}$ To evaluate the effect of preelection income, we further restrict the sample to freshmen, because only for them preelection income refers to private activity and can thus be interpreted as market skills (controlling for the previous occupation).

The results show that more years of schooling, past local government experiences, and higher preelection income increase the probability of running for election in a contestable (nonsafe) district. In other words, the harsher political competition, the higher the probability that political parties rely on high-quality candidates, that is, politicians with higher educational attainments or private income - both proxies for market skills - or politicians who proved their political ability in subsequent rounds of local elections, seen here as "filters" for politicians' quality (i.e., competence or honesty) in a federal system (Cooter, 2002; Myerson, 2006). Our results are robust to the use of different contestability measures. Interestingly, when we use the entire sample, the results are statistically significant only with the Safe3 indicator, while the other indicators - based on the lagged margin of victory - turn significant only when we restrict the sample by dropping incumbents. This is consistent with

\footnotetext{
${ }^{15}$ In principle, the characteristics of a high-quality candidate, if matched with a high-quality opponent, should not affect the margin of victory in the district, but - as shown by the case with few experts $(\mu<\eta / 2)$ in the theoretical model - in some districts a high-quality candidate of a party could be matched by a low-quality candidate of the other party: in these cases, the lagged margin of victory is affected by the characteristics of the incumbent who then runs for reelection. Focusing on no incumbents only, we can avoid this potential problem and address the decision of parties to allocate freshmen in safe versus swing districts.
} 
the concern that the endogeneity discussed above could downward bias the estimate of the association of political competition with candidates' quality.

The estimates in Table 6 (using the Safe1 indicator) suggest that two more years of schooling - equal to one standard deviation - increase the probability of running in a contestable district by 5.2 percentage points (that is, by about $7 \%$ with respect to the average). Similarly, past administrative experiences lower the probability of running in a safe district by 6.8 percentage points (that is, by about 9\%). Looking at freshmen, even if we control for previous job fixed effects, preelection income has a negative impact on the probability of running in safe districts for two out of the four indicators. In particular, if we look at Safe2, an increase in preelection income equal to one standard deviation (421,000 euros) reduces the probability of running in a safe district by 35.4 percentage points (that is, by about $41 \%$ ). Also a lower increase of 100,000 euros produces a sizable effect of 8.4 percentage points.

\subsection{Convergence of Politicians' Characteristics in Close Races}

In the previous section, we showed that good politicians are more likely to run (and hence to be elected) in contestable districts. But is this allocation strategy common to both political coalitions? Is there any difference in political selection between the right and left? To shed light on this point, we proceed in two steps. First, we look at any statistically significant difference in the observable characteristics of center-right versus center-left members of parliament. Second, we follow Lee, Moretti, and Butler (2004) and Lee (2008) and implement a Regression Discontinuity Design (RDD) on the margin of victory in single-member districts. ${ }^{16}$ Specifically, we calculate the margin of victory of the center-right coalition $(M V R)$ in each district: this measure is positive (negative) in all districts won by the center-right (center-left) coalition. We then look at the predetermined characteristics $\left(X_{i j t}\right)$ of politician $i$ elected in district $j$ at time $t$ and fit a third-order polynomial in $M V R$ on either side of the threshold $M V R=0$, at which the electoral result sharply changes in favor of the center-right:

$$
X_{i j t}=\alpha+\tau D_{i j t}+\left(\delta_{1} M V R_{i j t}+\ldots+\delta_{p} M V R_{i j t}^{p}\right)+\left(\beta_{1} D_{i j t} \cdot M V R_{i j t}+\ldots+\beta_{p} D_{i j t} \cdot M V R_{i j t}^{p}\right)+\psi_{i}
$$

\footnotetext{
${ }^{16}$ Ferreira and Gyourko (2009) and Pettersson-Lidbom (2008) use the same identification strategy to estimate the impact of political parties on policy outcomes in the US and Sweden, respectively. We look instead at political differences in candidates' attributes in close electoral races.
} 
where $D_{i j t}=1\left[M V R_{i j t}>0\right]$ and the error terms $\psi_{i j t}$ are clustered at the individual level. The parameter $\tau$ identifies the effect of interest: that is, whether politicians running in close races are intrinsically different in their observable characteristics according to the political coalition they belong to. The underlying assumption of this identification strategy is that electoral outcomes depend on both predictable elements (such as candidates' skills) and random chance, which is then crucial only for close races.

The first panel of Table 7 reports the results for the whole sample of members of parliament. On average, left-wing politicians are older, less educated, feature a longer parliament tenure and more local government experiences. The right-wing coalition recruits more entrepreneurs, self-employed, and lawyers; the left-wing coalition selects more professional politicians, teachers, college professors, union representatives, and females.

The two main political coalitions thus show very different patterns of political selection. Yet, the RDD evidence shows that they both converge to the same (high-quality) type in close races. The second panel of Table 7 reports the estimated discontinuity at a zero margin of victory, where there is no significant difference between center-right and center-left politicians in any demographic characteristic or previous market and political experience. In particular, education, parliament tenure, gender, and local government experience, despite being different in the whole sample, are perfectly balanced in close races. Figures 6 through 8 provide a graphical representation of the estimated polynomials and of the jumps at $M V R=0$. These figures clearly show a pattern of convergence in the predetermined attributes of political candidates. For instance, the center-left coalition has fewer candidates with high educational attainments, but allocates all of them to marginal districts, where the gap with the center-right coalition is thus filled. Only with respect to the previous occupations, the two coalitions may be supply constrained in certain characteristics, the center-left selecting fewer entrepreneurs and self-employed, and the center-right fewer teachers and professional politicians. These intrinsic differences remain also in close races.

\subsection{The Impact of Political Competition on Effort}

To evaluate whether the degree of ex-ante contestability of a district $\left(C_{i j t}\right)$ affects the in-office effort $\left(Y_{i j t}\right)$ of politician $i$ elected in district $j$ at time $t$, we run the following set of regressions 
(depending on the measure used to capture contestability):

$$
Y_{i j t}=\delta_{t}+\gamma_{j}+\tau C_{i j t}+\alpha_{1} X_{i j t}+\alpha_{2} P_{i j t}+\epsilon_{i j t}
$$

where $X_{i j t}$ are the predetermined characteristics, $P_{i j t}$ represent additional post-election characteristics affecting the absenteeism rate $Y_{i j t}$ (e.g., belonging to the majority coalition or being appointed to a government position), $\gamma_{j}$ and $\delta_{t}$ are regional and time dummies, and the error terms $\epsilon_{i j}$ are corrected for clustering at the individual level. The absenteeism rate is a measure of shirking or rent-extraction, since it excludes absences with a legitimate reason; moreover, we control for political appointments that may reduce parliament attendance. In the subsample of freshmen, we also control for preelection income, which has been shown to be a good predictor of outside income and shirking in parliamentary activity (see Gagliarducci, Nannicini, and Naticchioni, 2008).

By estimating the impact of ex-ante political competition on the future performance of elected officials, we want to assess whether the positive effect of electoral competition on selection leads also to better political outcomes, that is, whether more skilled candidates perform better once in office. Table 8 reports the estimation results. The empirical evidence shows that politicians elected in contestable districts display a lower absenteeism rate in electronic parliament votes. If we look at the Safe1 indicator in the subsample with no incumbents, running in a contestable district reduces the ex-post absences by 5 percentage points (that is, by about $16 \%$ with respect to the average). The effect is always significant at the $1 \%$ or $5 \%$ level, irrespective of the contestability measure we use. ${ }^{17}$

These findings may be driven by selection, but may also have an alternative explanation: members of parliament facing tougher political competition might choose to exert more effort in order to gain reelection. To disentangle whether the higher productivity of politicians elected in contestable districts arises from the selection of better candidates or from different reelection incentives, we exploit the (exogenous) changes in national coalitions discussed in Section 4.2, which altered the degree of contestability of certain districts from one election to the next. In Table 9, Safe3 is constructed as before (see equation 6), while Safe3-next uses the same method but refers to the next election (keeping into account the variations

\footnotetext{
${ }^{17}$ Since the absenteeism rate is bounded between 0 and 1, we also implemented the GLM estimator proposed by Papke and Wooldridge (1996); the results - available upon request - are almost identical to the OLS estimates reported in Table 8.
} 
that occured in the political alliances within coalitions). As outcome variable, we use the absenteeism rate during the last year of the legislative term, because at that time the new electoral coalitions are known and reelection incentives are probably at their maximum.

Column (1) shows that the effect of the ex-ante contestability (Safe3) remains strong: even if we control for future reelection incentives (Safe3-next), good politicians - elected in contestable districts - reduce their absences by 8.2 percentage points (about $35 \%$ with respect to the last-year average). Columns (2) and (3) confirm this result: (bad) politicians elected in safe districts make more absences at the end of the legislative term, both when their district has turned contestable and when it has remained safe. Selection hence matters. Similarly, in columns (3) and (4), we look at the impact of the future contestability of the district on last-year absences, controlling for the ex-ante contestability. As expected from the result in column (1), incentives are less relevant. Yet, there is still some evidence of an additional accountability effect for low-quality politicians: indeed, if a safe district turns contestable, (bad) politicians tend to exert more effort (by 4.1 percentage points, about 17\%). But the opposite does not hold: (good) politicians elected in contestable districts show a high productivity even when their district turns safe.

\section{Conclusion}

In this paper we address a recurring question in political economy: is electoral competition as quality enhancing as economic competition? Our suggestion is that not only the answer is positive, but that this could be due to the selection of high-quality candidates by political parties that want to attract non-aligned voters.

Our theoretical model provides a crucial role to the parties in selecting and allocating politicians to the different electoral districts. Hence, we disregard the type of self-selection by individuals studied in the citizen-candidate framework and analyze the effect of political competition on party selection. Our ideological parties select party loyalists and expertswho are highly valued by the swing voters - into districts in an attempt to increase their probability of winning the election. Political competition pushes political parties to allocate experts to the most contestable districts. 
The ground field to test this prediction is the Italian majoritarian political system between 1994 and 2006. And the empirical evidence confirms it. Ex-ante quality, as measured for instance by years of schooling, previous market income, and local government experience, increases the probability of running in a contestable district. Evidence from a regression discontinuity design shows that, despite being different on average, the characteristics of the two major political coalitions converge to high-quality levels in close races. Politicians elected in nonsafe districts have also a better level of ex-post quality, as measured by their absenteeism rate in parliament. This effort effect is driven more by the selection of better politicians than by reelection incentives. Accountability does however play an additional role, at least for low-quality candidates: if a safe district turns contestable, politicians tend to exert more effort. Yet, high-quality politicians, elected in contestable districts, do not reduce their ex-post productivity even when their district becomes safe.

Our results have normative implications. They suggest the adoption of institutions and policies aimed at enhancing both political competition and voters' information on the quality of individual candidates. For example, in a majoritarian system, the amount of ex-ante contestability could be increased by an "optimal" gerrymandering that evens out the relative shares of the main parties' ideological voters across electoral districts. We leave the study of these implications to future research. 


\section{References}

Alesina, A., 1988. Credibility and Policy Convergence in a Two-Party System with Rational Voters. American Economic Review 78(4), 796-806.

Bertrand, M., Schoar, A., 2003. Managing with Style: The Effect of Managers on Firm Policies. Quarterly Journal of Economics 118(4), 1169-1208.

Besley, T., 2004. Paying Politicians: Theory and Evidence. Journal of the European Economic Association 2, 193-215.

Besley, T., 2005. Political Selection. Journal of Economic Perspectives 19, 43-60.

Besley, T., Reynal-Querol, M., 2009. Do Democracies Select Better Leaders? Mimeo, LSE.

Besley, T., Coate, S., 1997. An Economic Model of Representative Democracy. Quarterly Journal of Economics 112, 85-114.

Besley, T., Persson, T., Sturm, D.M., 2008. Political Competition, Policy and Growth: Theory and Evidence from the United States. Mimeo, LSE.

Besley, T., Preston, I., 2007. Electoral Bias and Policy Choice: Theory and Evidence. Quarterly Journal of Economics 122(4), 1473-1510.

Carrillo, J.D., Mariotti, T., 2001. Electoral Competition and Politicians Turnover. European Economic Review 45, 1-25.

Caselli, F., Morelli, M., 2004. Bad Politicians. Journal of Public Economics 88, 759-782.

Coate, S., Knight, B., 2007. Socially Optimal Districting: A Theoretical and Empirical Exploration. Quarterly Journal of Economics 122(4), 1409-1471.

Cooter, R.D., 2002. Who Gets On Top in Democracy? Elections as Filters. The Selected Works of Robert Cooter, available at: http://works.bepress.com/robert_cooter/52.

Dal Bo, E., Dal Bo, P., Di Tella, R., 2006. Plata o Plomo? Bribe and Punishment in a Theory of Political Influence. American Political Science Review 100(1), 41-53.

Dal Bo, E., Di Tella, R., 2003. Capture by Threat. Journal of Political Economy 111(5).

Dal Bo, E., Dal Bo, P., Snyder, J., 2009. Political Dynasties. Review of Economic Studies 76(1), 115-142. 
Diermeier, D., Keane, M., Merlo, A., 2005. A Political Economy Model of Congressional Careers. American Economic Review 95, 347-373.

Ferraz, C., Finan, C., 2008. Motivating Politicians: The Impacts of Monetary Incentives on Quality and Performance. IZA Discussion Paper 3411.

Ferreira, F., Gyourko, J., 2009. Do Political Parties Matter? Evidence from U.S. Cities. Quarterly Journal of Economics 124(1), 349-397.

Gagliarducci, S., Nannicini, T., 2008. Do Better Paid Politicians Perform Better? Disentangling Incentives from Selection. IGIER Discussion Paper 346.

Gagliarducci, S., Nannicini, T., Naticchioni, P., 2008. Outside Income and Moral Hazard: The Elusive Quest for Good Politicians. IZA Discussion Paper 3295.

Galasso, V., Nannicini, T., 2009. Political Selection Under Alternative Electoral Rules. Mimeo, Bocconi University.

Jones, B., Olken, B., 2005. Do Leaders Matter? National Leadership and Growth Since World War II. Quarterly Journal of Economics 120(3), 835-864.

Lee, D.S., Moretti, E., Butler, M.J., 2004. Do Voters Affect or Elect Policies? Evidence from the U.S. House. Quarterly Journal of Economics 119, 807-859.

Lee, D.S., 2008. Randomized Experiments from Non-random Selection in the U.S. House Elections. Journal of Econometrics 142(2), 675-697.

Lindbeck, A., Weibull, J., 1987. Balanced-Budget Redistribution as the Outcome of Political Competition. Public Choice 52, 273-97.

Lizzeri, A., Persico, N., 2001. The Provision of Public Goods under Alternative Electoral Incentives. American Economic Review 91(1), 225-239.

Lizzeri, A., Persico, N., 2005. The Drawbacks of Electoral Competition. Journal of the European Economic Association 3, 1318-1348.

Mattozzi, A., Merlo, A., 2006. Mediocracy. Mimeo, University of Pennsylvania.

Mattozzi, A., Merlo, A., 2008. Political Careers or Career Politicians. Journal of Public Economics 92, 597-608.

Merlo, A., Galasso, V., Landi, M., Mattozzi, A., 2008. The Labor Market of Italian Politicians. Mimeo, Fondazione Rodolfo DeBenedetti. 
Messner, M., Polborn, M., 2004. Paying Politicians. Journal of Public Economics 88, 24232445.

Milesi-Ferretti, G.M., Perotti, R., Rostagno, M., 2002. Electoral Systems and Public Spending. Quarterly Journal of Economics 117(2), 609-657.

Myerson, R.B., 2006. Federalism and Incentives for Success of Democracy. Quarterly Journal of Political Science 1, 3-23.

Osborne, M.J., Slivinski, A., 1996. A Model of Political Competition with Citizen Candidates. Quarterly Journal of Economics 111(1), 65-96.

Papke, L.E., Wooldridge, J., 1996. Econometric Methods for Fractional Response Variables with an Application to 401(k) Plan Participation Rates. Journal of Applied Econometrics 11, 619-632.

Persico, N., Rodriguez Pueblita, J.C., Silverman D., 2009. Factions and Political Competition. Mimeo, NYU.

Persson, T., Tabellini, G., 2000. Political Economics. MIT Press.

Pettersson-Lidbom, P., 2008. Do Parties Matter for Economic Outcomes? A RegressionDiscontinuity Approach. Journal of the European Economic Association 6, 1037-1056.

Stigler, G.J., 1972. Economic Competition and Political Competition. Public Choice 13, 91-106.

Poutvaara, P., Takalo, T., 2007. Candidate Quality. International Tax and Public Finance $14,70-27$.

Stromberg, D., 2008. How the Electoral College Influences Campaigns and Policy: The Probability of Being Florida. American Economic Review 98(3), 769-807.

Wittman, D., 1989. Why Democracies Produce Efficient Results. Journal of Political Economy $97(6)$, 1395-1424.

Zhang, Y., Congleton, R., 2008. Is It All about Competence? The Human Capital of U.S. Presidents and Economic Performance. Mimeo, George Mason University. 


\section{Appendix}

\section{Proof of Proposition 1}

First, define $H\left(\Lambda_{i}^{L}\right)=G\left(\lambda_{I I}^{i}\right)-G\left(\lambda_{I}^{i}\right)$ as the mass of districts in the interval $\Lambda_{i}^{L}$. Parties' objective in allocating their experts is to maximize the probability of winning the election, i.e., of winning more than $50 \%$ of the districts. Consider party $L$. Its probability of winning a district $k$ is $\delta<d_{k}=\rho\left(V_{C}\left(z_{L}^{k}\right)-V_{C}\left(z_{R}^{k}\right)\right)-\lambda_{k}$. Thus, party $L$ allocates experts to districts in order to modify $V_{C}\left(z_{L}^{k}\right)$ in the marginal districts. These are the district(s) such that, given the shock, winning the $\operatorname{district}(\mathrm{s})$ increases the probability of winning the election. For instance, if candidates are matched in every districts, we would have $V_{C}\left(z_{L}^{k}\right)=V_{C}\left(z_{R}^{k}\right) \forall k$, and party $L$ probability of winning the election would be $\delta<-\lambda_{0}$, so that the interval of districts around $\lambda_{0}$ would be pivotal.

Consider first the case that parties have enough experts to span the interval between $\lambda_{w}$ and $\lambda_{0}$, i.e., $\mu>\eta / 2$. Consider an allocation $\Lambda^{L}$ by party $L$ which includes $\Lambda_{i}^{L}$ s.t. $\left[\lambda_{w}, \lambda_{\Xi}\right] \subset$ $\Lambda_{i}^{L}$. It is easy to see that an allocation $\Lambda^{R}$ by party $R$ which includes $\Lambda_{i}^{R}$ s.t. $\left[\lambda_{\varepsilon}, \lambda_{W}\right] \subset \Lambda_{i}^{R}$ is a best response to $\Lambda^{L}$. In fact, given $\Lambda^{L}$, by sending its experts to the interval $\left[\lambda_{\varepsilon}, \lambda_{W}\right]$, party $R$ restores its probability of winning the election to $1 / 2$. In particular, party $R$ wins the election for $\delta>0$, and $L$ for $\delta<0$. Allocating additional experts may modify the share of seats won by party $R$, but not its probability of winning the election. The same reasoning shows that $\Lambda^{L}$ with $\Lambda_{i}^{L}$ s.t. $\left[\lambda_{w}, \lambda_{\Xi}\right] \subset \Lambda_{i}^{L}$ is a best response to $\Lambda^{R}$ with $\Lambda_{i}^{R}$ s.t. $\left[\lambda_{\varepsilon}, \lambda_{W}\right] \subset \Lambda_{i}^{R}$. Hence, a pair of allocations $\Lambda^{L}$, including $\Lambda_{i}^{L}$ s.t. $\left[\lambda_{w}, \lambda_{\Xi}\right] \subset \Lambda_{i}^{L}$ and $H\left(\Lambda^{L}\right)=\sum_{i} H\left(\Lambda_{i}^{L}\right)=\mu$, and $\Lambda^{R}$, including $\Lambda_{i}^{R}$ s.t. $\left[\lambda_{\varepsilon}, \lambda_{W}\right] \subset \Lambda_{i}^{R}$ and $H\left(\Lambda^{R}\right)=\sum_{i} H\left(\Lambda_{i}^{R}\right)=\mu$, are a Nash equilibrium of the allocation game.

To prove than any equilibrium allocation $\Lambda^{L}$ has to include $\Lambda_{i}^{L}$ s.t. $\left[\lambda_{w}, \lambda_{\Xi}\right] \subset \Lambda_{i}^{L}$, consider first an allocation $\widehat{\Lambda}^{L}$ with $\widehat{\Lambda}_{i}^{L}=\left[\lambda_{I}^{i}, \lambda_{I I}^{i}\right]$ s.t. $0>\lambda_{I}^{i}>\lambda_{w}$ and $\lambda_{I I}^{i}>\lambda_{\Xi}$, and no other experts in $\left[\lambda_{w}, \lambda_{I}\right]$. Party- $R$ best response is to allocate its experts in $\left[\lambda_{w}, \lambda_{I}\right] \cup\left[\lambda_{0}, \lambda_{I I}\right]$. Following this strategy, party $R$ wins the election with a probability greater than $1 / 2$, since for $\delta=0$ party $R$ wins all districts with $\lambda>0$ (and hence $50 \%$ ), but also the districts in $\left[\lambda_{w}, \lambda_{I}\right]$. Hence, $\widehat{\Lambda}^{L}$ cannot be part of an equilibrium since simply matching the previous best response by party $R$ would give party $L 50 \%$ probability of winning the election. Finally, it is trivial to show that an equilibrium allocation $\Lambda^{L}$ has to include the interval $\left[\lambda_{\varepsilon}, \lambda_{\Xi}\right]$. Consider $\widehat{\Lambda}^{L}$ with $\widehat{\Lambda}_{i}^{L}=\left[\lambda_{I}^{i}, \lambda_{I I}^{i}\right] \in\left[\lambda_{w}, \lambda_{\varepsilon}\right]$ and $\widehat{\Lambda}_{j}^{L}=\left[\lambda_{I}^{j}, \lambda_{I I}^{j}\right] \in\left[\lambda_{\Xi}, \lambda_{W}\right]$. Party- $R$ best response would be $\Lambda^{R}$ such that $\Lambda_{i}^{R}=\left[\lambda_{\varepsilon}, \lambda_{W}\right]$, which yields party $R$ a winning probability greater than $1 / 2$. Hence, $\widehat{\Lambda}^{L}$ cannot be part of an equilibrium.

For $\mu \leq \eta / 2$, suppose that party $L$ allocates its experts to $\left[\lambda_{0}, \lambda_{B}\right]$. What is party$R$ best response? To re-establish its probability of winning the election to $1 / 2$, party $R$ 
can send its experts to $\left[\lambda_{b}, \lambda_{0}\right]$. As displayed in figure 5 , party $L$ wins the election for $\delta<\max \left[-\lambda_{B},-\lambda_{b}-W\right]$, party $R$ for $\delta>\min \left[-\lambda_{b},-\lambda_{B}+W\right]$, and the election is tied for $\delta \in\left[-\lambda_{B},-\lambda_{b}\right]$. Finally, notice that party $R$ cannot increase its probability of winning the election above $1 / 2$ by allocation experts in other districts (see figure 5 ). Hence, party- $L$ allocation in $\left[\lambda_{0}, \lambda_{B}\right]$ and party- $R$ allocation in $\left[\lambda_{b}, \lambda_{0}\right]$ is an equilibrium.

To prove that no other equilibrium allocation exists, first notice that allocating experts outside the interval $\left[\lambda_{w}, \lambda_{W}\right]$ is never part of an equilibrium, since it does not modify the probability of winning election, which can instead be achieved by allocating experts in this

interval. Consider party-L allocation $\Lambda^{L}=\left[\lambda_{b}, \lambda_{0}\right]$. Party- $R$ best response would be to allocate experts $\left[\lambda_{w}, \lambda_{b}\right]$, which would yield party $R$ a winning probability above $1 / 2$, since for $\delta=0$ party $R$ would win in districts with $\lambda>0$ and in $\left[\lambda_{w}, \lambda_{b}\right]$. The same reasoning applies to any $\widehat{\Lambda}^{L}=\left[\lambda_{I}, \lambda_{I I}\right]$ s.t. $\lambda_{I} \in\left[\lambda_{w}, \lambda_{0}\right), \lambda_{I I} \in\left[\lambda_{w}, \lambda_{b}\right)$ and $G\left(\lambda_{I I}\right)-G\left(\lambda_{I}\right)=\mu$. And to $\widehat{\Lambda}^{L}=\left[\lambda_{I}, \lambda_{W}\right]$ and $G\left(\lambda_{W}\right)-G\left(\lambda_{I}\right)=\mu$.

\section{Proof of Corollary 2}

First, simply notice that by Proposition 1 for $\mu>\eta / 2$ the share of experts in the interval $\left[\lambda_{\varepsilon}, \lambda_{\Xi}\right]$ is $100 \%$. Second, notice that for $\mu \leq \eta / 2$, given the equilibrium allocations described in Proposition 1, the share of experts in the interval $\left[\lambda_{\varepsilon}, \lambda_{\Xi}\right]$ could be equal to $50 \%$ when only the experts of the winning party are elected. Then, the share of experts elected in $\left[\lambda, \lambda_{\varepsilon}\right] \cup\left[\lambda_{\Xi},-\lambda\right] \forall \lambda<\lambda_{\varepsilon}$ is (weakly) less than $50 \%$ and so is the share of elected experts. 


\section{Tables and Figures}

Table 1: Patterns of political victory in single-member districts

\begin{tabular}{lcc}
\hline \hline Pattern & Obs. & Percent \\
\hline Left-Left-Left & 179 & 25.39 \\
Right-Left-Left & 55 & 7.80 \\
Left-Right-Left & 12 & 1.70 \\
Right-Right-Left & 9 & 1.28 \\
Left-Left-Right & 42 & 5.96 \\
Right-Left-Right & 117 & 16.60 \\
Left-Right-Right & 25 & 3.55 \\
Right-Right-Right & 243 & 34.47 \\
Other & 23 & 3.26 \\
\hline Total & 705 & 100.00 \\
\hline Notes. Left stands for victory of the center-left coalition; Right \\
stands for victory of the center-right coalition; Other means vic- \\
tory of at least one third-coalition candidate. The first, second, \\
and third term in each pattern refer to the XII, XIII, and XIV \\
legislative term, respectively.
\end{tabular}

Table 2: Swing districts according to geographic location

\begin{tabular}{lcc}
\hline \hline & $\begin{array}{c}\text { No swing } \\
\text { (percent) }\end{array}$ & $\begin{array}{c}\text { Swing } \\
\text { (percent) }\end{array}$ \\
\hline North West & 70.49 & 29.51 \\
North East & 77.91 & 22.09 \\
Center & 78.83 & 21.17 \\
South & 65.14 & 34.86 \\
Islands & 69.75 & 30.25 \\
\hline Total & 72.06 & 27.94 \\
\hline \hline Notes. Swing is equal to one if the winner belongs to a differ- \\
ent coalition with respect to the incumbent. ISTAT geographic \\
classification. Legislative terms XIII and XIV; 1,410 districts.
\end{tabular}


Table 3: Swing districts according to the lagged margin of victory

\begin{tabular}{|c|c|c|}
\hline & $\begin{array}{l}\text { No swing } \\
\text { (percent) }\end{array}$ & $\begin{array}{c}\text { Swing } \\
\text { (percent) }\end{array}$ \\
\hline \multicolumn{3}{|c|}{$\overline{\text { Margin of victory }}$} \\
\hline $0-5$ & 59.31 & 40.69 \\
\hline $5-10$ & 56.12 & 43.88 \\
\hline $10-15$ & 72.31 & 27.69 \\
\hline $15-20$ & 85.21 & 14.79 \\
\hline $20-25$ & 87.79 & 12.21 \\
\hline $25-30$ & 93.62 & 6.38 \\
\hline$>30$ & 97.35 & 2.65 \\
\hline \multicolumn{3}{|l|}{ Safe1 } \\
\hline$\overline{\mathrm{No}}$ & 59.31 & 40.69 \\
\hline Yes & 77.16 & 22.84 \\
\hline \multicolumn{3}{|l|}{ Safe2 } \\
\hline$\overline{\mathrm{No}}$ & 57.96 & 42.04 \\
\hline Yes & 85.83 & 14.17 \\
\hline \multicolumn{3}{|l|}{ Safe3 } \\
\hline$\overline{\mathrm{No}}$ & 69.87 & 30.13 \\
\hline Yes & 75.22 & 24.78 \\
\hline Total & 72.06 & 27.94 \\
\hline \multicolumn{3}{|c|}{$\begin{array}{l}\text { Notes. Swing is equal to one if the winner belongs to a different } \\
\text { coalition with respect to the incumbent. Margin of victory is the } \\
\text { lagged margin of victory in the single-member district. Safe } 1 \text { is } \\
\text { equal to one if the lagged margin is greater than } 5 \text { percentage } \\
\text { points. Safe2 is equal to one if the lagged margin is greater than } \\
10 \text { percentage points. Safe3 is equal to one if }(1-L-R) / \mid L- \\
R \mid<1 \text {, where } L(R) \text { captures the expected share of voters for } \\
\text { the center-left (center-right) coalition, estimated by means of } \\
\text { ideological votes at the previous European elections. Legislative } \\
\text { terms XIII and XIV; } 1,410 \text { districts. }\end{array}$} \\
\hline
\end{tabular}


Table 4: Ex-ante characteristics of the members of parliament

\begin{tabular}{|c|c|c|c|c|c|}
\hline & \multicolumn{2}{|c|}{ Safed } & \multirow[b]{2}{*}{ Difference } & \multirow[b]{2}{*}{-diff95\% } & \multirow[b]{2}{*}{$+\operatorname{diff} 95 \%$} \\
\hline & No & Yes & & & \\
\hline Male & 0.928 & 0.906 & 0.022 & -0.007 & 0.051 \\
\hline Age & 51.416 & 50.728 & 0.688 & -0.289 & 1.665 \\
\hline Married & 0.824 & 0.791 & 0.033 & -0.009 & 0.074 \\
\hline Years of schooling & 16.103 & 15.754 & 0.349 & 0.132 & 0.567 \\
\hline Freshman & 0.458 & 0.387 & 0.071 & 0.019 & 0.122 \\
\hline Incumbent & 0.277 & 0.351 & -0.074 & -0.122 & -0.025 \\
\hline Parliament appointment & 0.098 & 0.151 & -0.054 & -0.088 & -0.019 \\
\hline Govt. appointment & 0.065 & 0.111 & -0.046 & -0.076 & -0.017 \\
\hline Local govt. experience & 0.608 & 0.558 & 0.050 & -0.001 & 0.102 \\
\hline Preelection income & 0.113 & 0.083 & 0.029 & 0.005 & 0.053 \\
\hline Lawyer & 0.164 & 0.132 & 0.032 & -0.006 & 0.069 \\
\hline Party officer & 0.053 & 0.090 & -0.037 & -0.064 & -0.010 \\
\hline Teacher & 0.088 & 0.077 & 0.011 & -0.018 & 0.040 \\
\hline Clerk & 0.029 & 0.051 & -0.022 & -0.043 & -0.001 \\
\hline Physician & 0.094 & 0.061 & 0.032 & 0.004 & 0.061 \\
\hline Entrepreneur & 0.091 & 0.095 & -0.005 & -0.035 & 0.026 \\
\hline Self employed & 0.092 & 0.098 & -0.006 & -0.037 & 0.025 \\
\hline Executive & 0.089 & 0.097 & -0.008 & -0.038 & 0.023 \\
\hline Professor & 0.091 & 0.118 & -0.027 & -0.060 & 0.005 \\
\hline Bureaucrat & 0.075 & 0.064 & 0.011 & -0.016 & 0.037 \\
\hline Union representative & 0.023 & 0.023 & 0.001 & -0.015 & 0.016 \\
\hline Journalist & 0.069 & 0.064 & 0.005 & -0.022 & 0.031 \\
\hline \multicolumn{6}{|c|}{$\begin{array}{l}\text { Notes. Safe2 is equal to one if the lagged margin of victory is greater than } 10 \text { percentage points. -diff95\% and } \\
+ \text { diff95\% represent the lower and upper bound of the } 95 \% \text { confidence interval of Difference, respectively. All } \\
\text { variables are dummies, except Age, Years of schooling, and Preelection income (in million of euros, 2004 prices). } \\
\text { Freshman means that the previous parliamentary tenure is zero. Parliament appointment captures whether the } \\
\text { politician has previously been president or vice president of the parliament, or of a single committee. Government } \\
\text { appointment captures whether the politician has previously been minister or vice minister. Local Government } \\
\text { Experience stands for previous institutional experience at the local level (e.g., mayor). Preelection income is the } \\
\text { total taxable income in the year before election (freshmen only). Job dummies refer to the preelection occupation } \\
\text { and the omitted category includes blue collars and students. Legislative terms XIII and XIV; } 1,307 \text { observations. }\end{array}$} \\
\hline
\end{tabular}


Table 5: Absences and appointments of the members of parliament

\begin{tabular}{l}
\hline \hline \\
\cline { 2 - 3 }
\end{tabular}




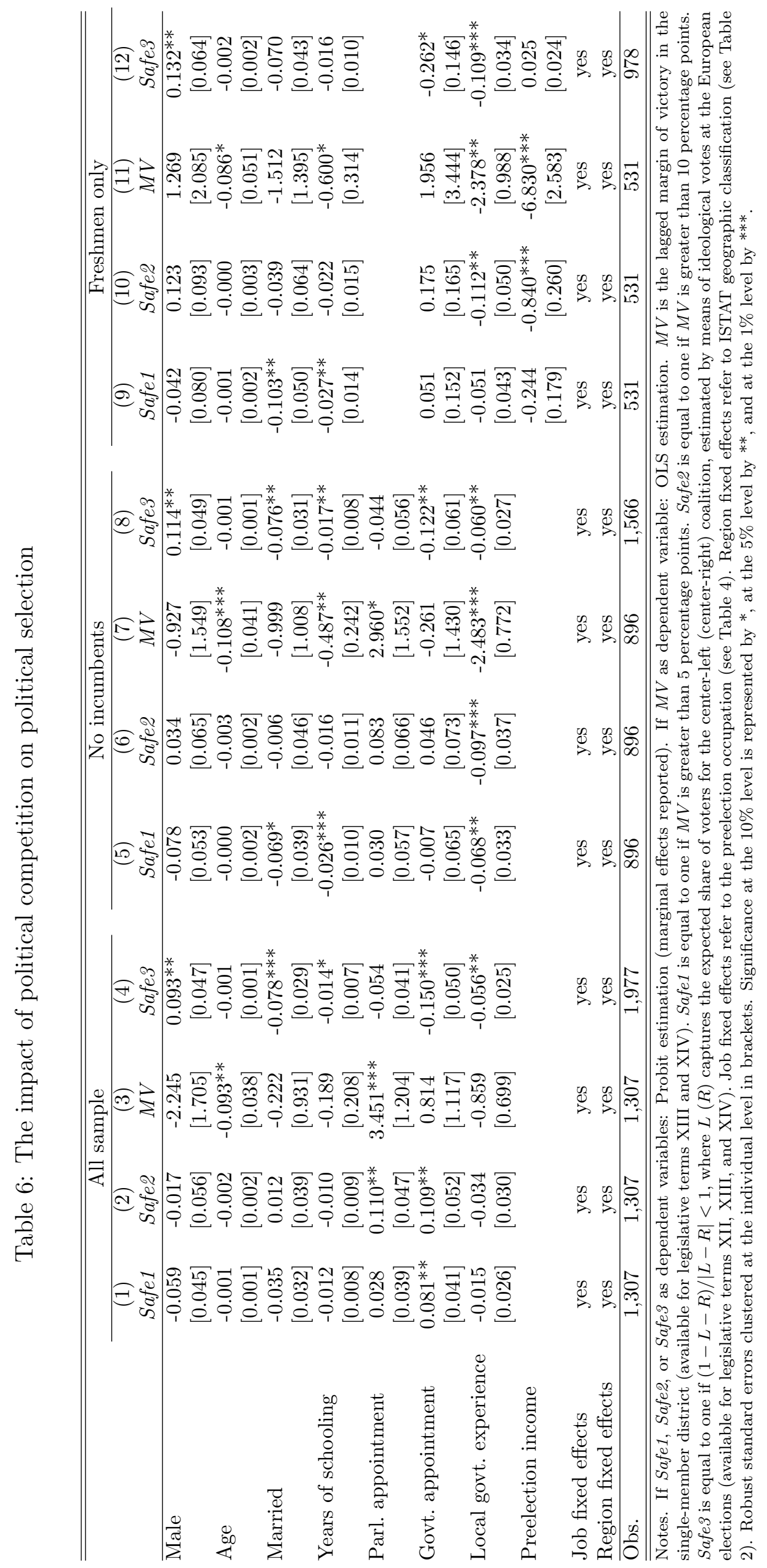


Table 7: Partisan differences in political selection, all versus close races

\begin{tabular}{|c|c|c|c|c|}
\hline & \multicolumn{2}{|c|}{ All sample } & \multicolumn{2}{|c|}{ Polynomial in $M V R \in[-25,+25]$} \\
\hline & $\begin{array}{c}\text { Difference } \\
\text { Right vs. Left }\end{array}$ & Std.Err. & $\begin{array}{l}\text { Discontinuity } \\
\text { Right vs. Left }\end{array}$ & Std.Err. \\
\hline Male & $0.059^{* * *}$ & {$[0.013]$} & 0.009 & {$[0.042]$} \\
\hline Age & $-0.804^{*}$ & {$[0.427]$} & -0.643 & {$[1.549]$} \\
\hline Married & 0.006 & {$[0.019]$} & 0.063 & {$[0.063]$} \\
\hline Years of schooling & $0.327^{* * *}$ & {$[0.095]$} & 0.13 & {$[0.290]$} \\
\hline Freshman & $0.106^{* * *}$ & {$[0.023]$} & -0.013 & {$[0.076]$} \\
\hline Parl. appointment & $-0.039 * * *$ & {$[0.013]$} & 0.008 & [0.043] \\
\hline Govt. appointment & -0.016 & {$[0.011]$} & 0.000 & {$[0.034]$} \\
\hline Local govt. experience & $-0.039^{*}$ & {$[0.023]$} & 0.033 & {$[0.079]$} \\
\hline Preelection Income & 0.056 & {$[0.035]$} & 0.011 & [0.048] \\
\hline Lawyer & $0.119^{* * *}$ & {$[0.016]$} & 0.019 & {$[0.060]$} \\
\hline Politician & $-0.125^{* * *}$ & {$[0.011]$} & $-0.076^{* *}$ & {$[0.034]$} \\
\hline Teacher & $-0.059 * * *$ & {$[0.013]$} & $-0.153^{* * *}$ & {$[0.053]$} \\
\hline Clerk & $-0.054^{* * *}$ & [0.009] & 0.012 & [0.028] \\
\hline Physician & $0.025^{*}$ & {$[0.013]$} & 0.06 & [0.048] \\
\hline Entrepreneur & $0.137^{* * *}$ & {$[0.013]$} & $0.077^{*}$ & {$[0.040]$} \\
\hline Selfemp & $0.091^{* * *}$ & {$[0.014]$} & $0.111^{* *}$ & [0.048] \\
\hline Manager & $0.022^{*}$ & {$[0.012]$} & $0.077^{*}$ & {$[0.041]$} \\
\hline Professor & $-0.092^{* * *}$ & {$[0.014]$} & $-0.089^{*}$ & {$[0.046]$} \\
\hline Bureaucrat & -0.002 & {$[0.011]$} & -0.003 & {$[0.037]$} \\
\hline Union representative & $-0.033^{* * *}$ & {$[0.006]$} & -0.029 & {$[0.018]$} \\
\hline Journalist & -0.005 & {$[0.011]$} & 0.033 & {$[0.032]$} \\
\hline Obs. & 1,919 & & 1,656 & \\
\hline $\begin{array}{l}\text { Notes. Difference is the di } \\
\text { characteristics of center-lef } \\
\text { i.e., the discontinuity at ze } \\
(M V R) \text {, fitted over the in } \\
\text { level is represented by }{ }^{*} \text {, at } \\
\text { except Age, Years of school } \\
\text { previous parliamentary ten } \\
\text { president or vice president } \\
\text { the politician has previous } \\
\text { institutional experience at } \\
\text { before election (freshmen or } \\
\text { blue collars and students. I }\end{array}$ & $\begin{array}{l}\text { ence between the } \\
\text { oliticians in all d } \\
\text { of a split } 3^{r d} \text {-orde } \\
\text { val } M V R \in[-25 \\
\text { e } 5 \% \text { level by } * * \text {, } \\
\text {, and Preelection } \\
\text { is zero. Parliame } \\
\text { he parliament, or } \\
\text { been minister or } \\
\text { local level (e.g., r } \\
\text { Job dummies re } \\
\text { islative terms XII }\end{array}$ & $\begin{array}{l}\text { erage chara } \\
\text { ricts. Discc } \\
\text { bolynomial } \\
25] \text {. Stand } \\
\text { d at the } 1 \% \\
\text { ome (in mil } \\
\text { appointmen } \\
\text { a single con } \\
\text { minister. } \\
\text { yor). Preele } \\
\text { to the pree }\end{array}$ & $\begin{array}{l}\text { cs of center-right } p \\
y \text { is the estimated } \\
\text { hargin of victory o } \\
\text { rs are in brackets } \\
\text { y***. All depend } \\
\text { uros, } 2004 \text { prices). } \\
\text { es whether the pol } \\
\text { Government app } \\
\text { Government Expe } \\
\text { come is the total } \\
\text { ccupation and the }\end{array}$ & $\begin{array}{l}\text { is and the average } \\
\text { ce for close races } \\
\text { iter-right coalitior } \\
\text { cance at the } 10 \% \\
\text { bles are dummies } \\
\text { an means that the } \\
\text { as previously beer } \\
\text { captures whethe } \\
\text { ands for previous } \\
\text { ncome in the year } \\
\text { category includes }\end{array}$ \\
\hline
\end{tabular}




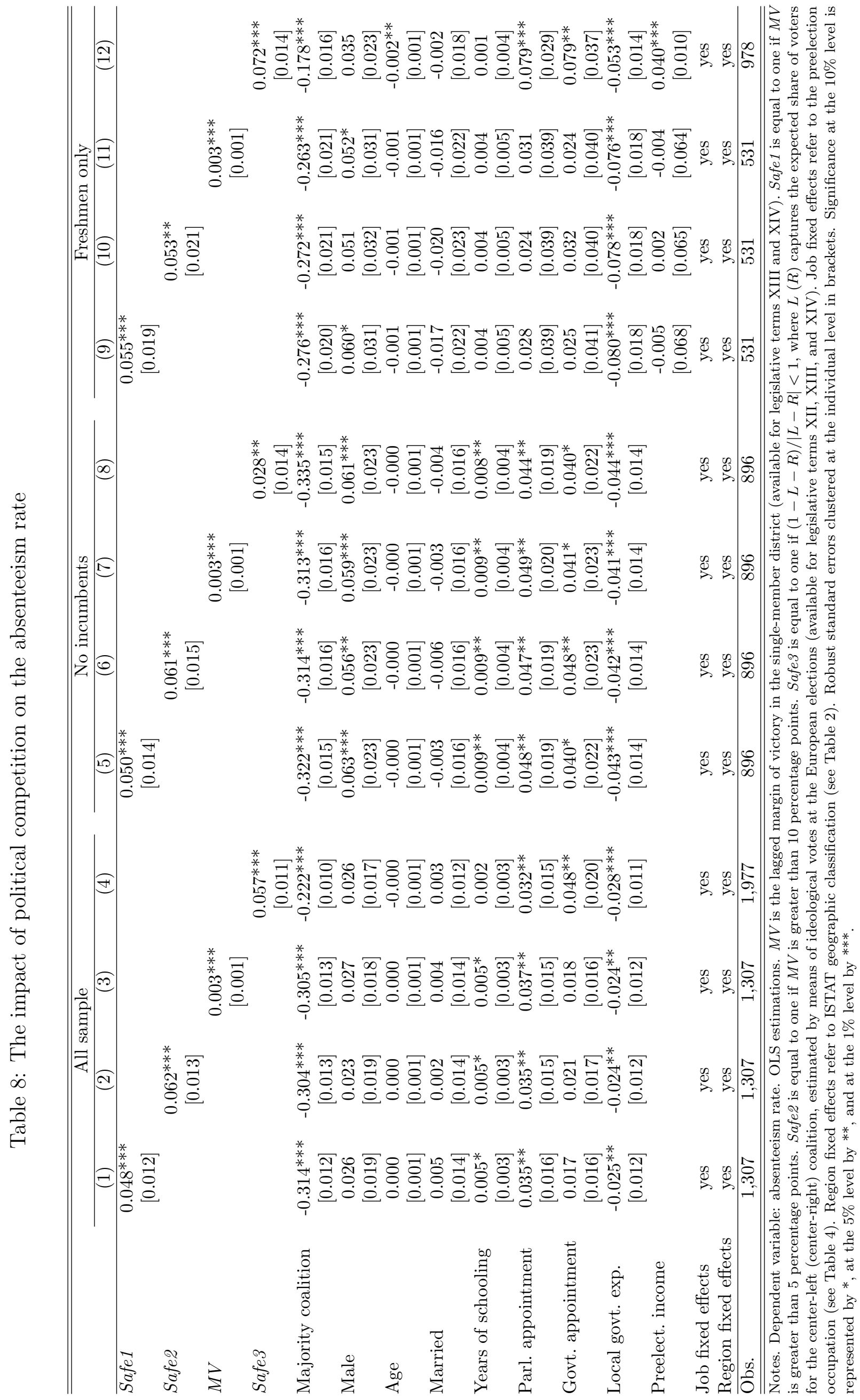


Table 9: Political competition and absences in the last year of the term

\begin{tabular}{|c|c|c|c|c|c|}
\hline & $\begin{array}{c}(1) \\
\text { All sample }\end{array}$ & $\begin{array}{c}(2) \\
\text { Safe3-next }=0\end{array}$ & $\begin{array}{c}(3) \\
\text { Safe3-next }=1\end{array}$ & $\begin{array}{c}(4) \\
\text { Safe3 }=0\end{array}$ & $\begin{array}{c}(5) \\
\text { Safe3 }=1\end{array}$ \\
\hline \multirow[t]{2}{*}{ Safe3 } & $0.087^{* * *}$ & $0.082^{* * *}$ & $0.063^{*}$ & & \\
\hline & {$[0.016]$} & {$[0.021]$} & {$[0.034]$} & & \\
\hline \multirow[t]{2}{*}{ Safe3-next } & 0.011 & & & -0.039 & $0.041^{* *}$ \\
\hline & {$[0.015]$} & & & {$[0.027]$} & {$[0.020]$} \\
\hline \multirow[t]{2}{*}{ Majority coalition } & $-0.042^{* * *}$ & $-0.117^{* * *}$ & 0.036 & $-0.107^{* * *}$ & -0.008 \\
\hline & {$[0.014]$} & {$[0.022]$} & {$[0.022]$} & {$[0.022]$} & {$[0.019]$} \\
\hline \multirow[t]{2}{*}{ Male } & -0.002 & -0.008 & 0.006 & -0.002 & 0.002 \\
\hline & {$[0.027]$} & {$[0.031]$} & {$[0.037]$} & {$[0.038]$} & {$[0.037]$} \\
\hline \multirow[t]{2}{*}{ Age } & -0.001 & 0.000 & -0.002 & 0.001 & -0.002 \\
\hline & {$[0.001]$} & {$[0.001]$} & {$[0.001]$} & {$[0.002]$} & {$[0.001]$} \\
\hline \multirow[t]{2}{*}{ Married } & 0.015 & -0.003 & 0.040 & $-0.046^{*}$ & $0.043^{*}$ \\
\hline & {$[0.018]$} & {$[0.021]$} & {$[0.025]$} & {$[0.025]$} & {$[0.022]$} \\
\hline \multirow[t]{2}{*}{ Years of schooling } & 0.000 & 0.007 & -0.007 & 0.010 & -0.005 \\
\hline & {$[0.005]$} & {$[0.006]$} & {$[0.007]$} & {$[0.006]$} & {$[0.006]$} \\
\hline \multirow[t]{2}{*}{ Parl. appointment } & 0.029 & -0.022 & $0.111^{* * *}$ & -0.018 & 0.041 \\
\hline & {$[0.025]$} & {$[0.029]$} & {$[0.042]$} & {$[0.037]$} & {$[0.032]$} \\
\hline \multirow[t]{2}{*}{ Govt. appointment } & $0.080^{* *}$ & $0.069^{*}$ & $0.118^{*}$ & $0.089 * *$ & 0.071 \\
\hline & {$[0.034]$} & {$[0.037]$} & {$[0.061]$} & {$[0.045]$} & {$[0.044]$} \\
\hline \multirow[t]{2}{*}{ Local govt. experience } & -0.009 & -0.017 & 0.014 & $-0.047^{* *}$ & 0.015 \\
\hline & {$[0.015]$} & {$[0.019]$} & {$[0.023]$} & {$[0.023]$} & {$[0.020]$} \\
\hline Job fixed effects & yes & yes & yes & yes & \\
\hline Region fixed effects & yes & yes & yes & yes & \\
\hline Obs. & 902 & 525 & 377 & 326 & 576 \\
\hline \multicolumn{6}{|c|}{$\begin{array}{l}\text { Notes. Dependent variable: absenteeism rate in the last year of the legislative term. OLS estimations. House of Representatives } \\
\text { only. Safe3 is equal to one if }(1-L-R) /|L-R|<1 \text {, where } L(R) \text { captures the expected share of voters for the center-left } \\
\text { (center-right) coalition, estimated by means of the votes at the previous European elections (available for legislative terms XII, } \\
\text { XIII, and XIV). Safe3-next is calculated in the same way but keeping into account the variations in national political coalitions } \\
\text { at the following election, in order to capture reelection incentives. Job fixed effects refer to the preelection occupation (see Table } \\
\text { 4). Region fixed effects refer to ISTAT geographic classification (see Table } 2 \text { ). Robust standard errors clustered at the individual } \\
\text { level in brackets. Significance at the } 10 \% \text { level is represented by } * \text {, at the } 5 \% \text { level by }{ }^{* *} \text {, and at the } 1 \% \text { level by } * * * \text {. }\end{array}$} \\
\hline
\end{tabular}


Figure 1: Distribution of districts and probability of winning the election

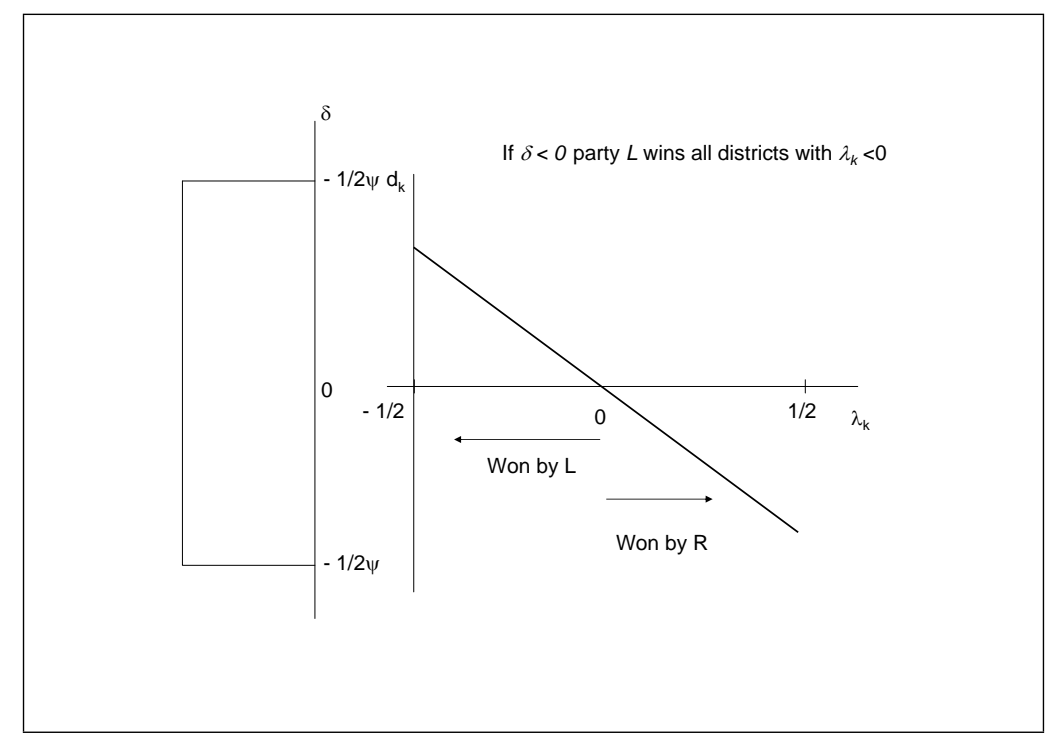

Figure 2: Allocation of experts and probability of winning, pivotal districts

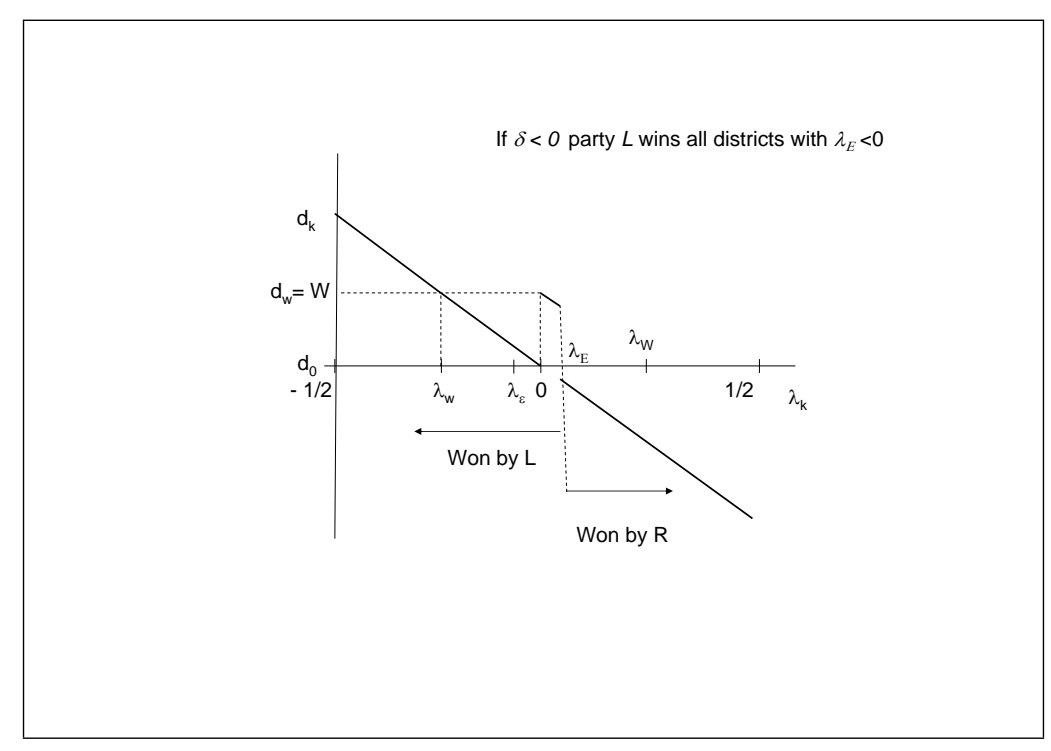


Figure 3: Allocation of experts and probability of winning if $\mu>\eta / 2$, first case

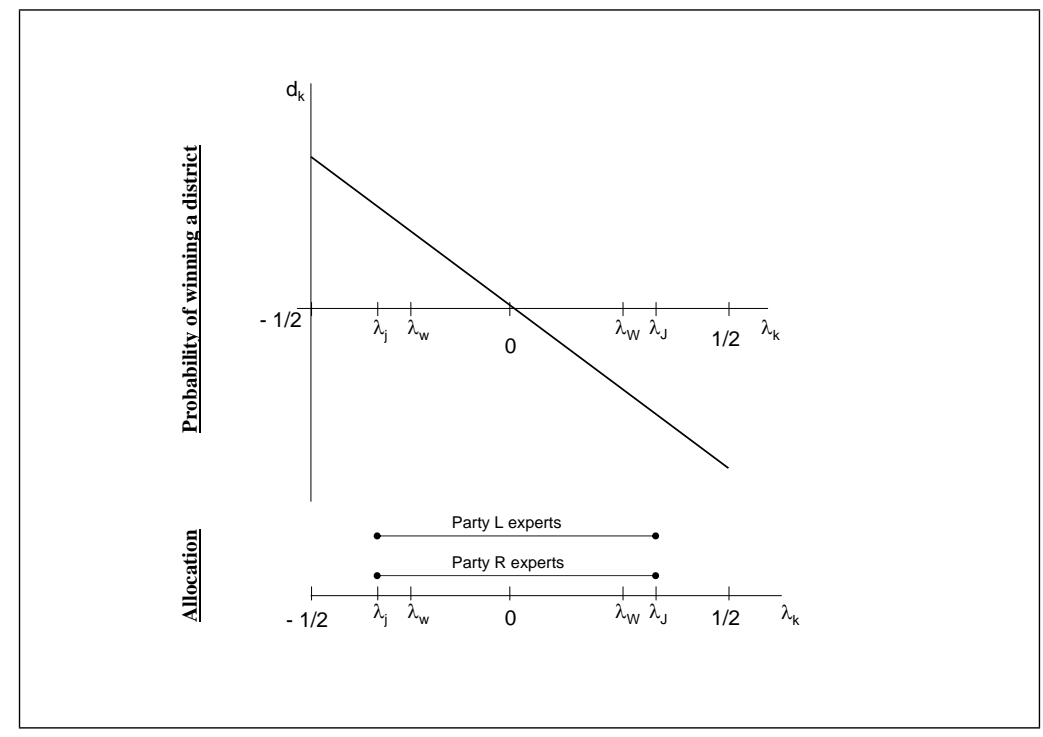

Figure 4: Allocation of experts and probability of winning if $\mu>\eta / 2$, second case

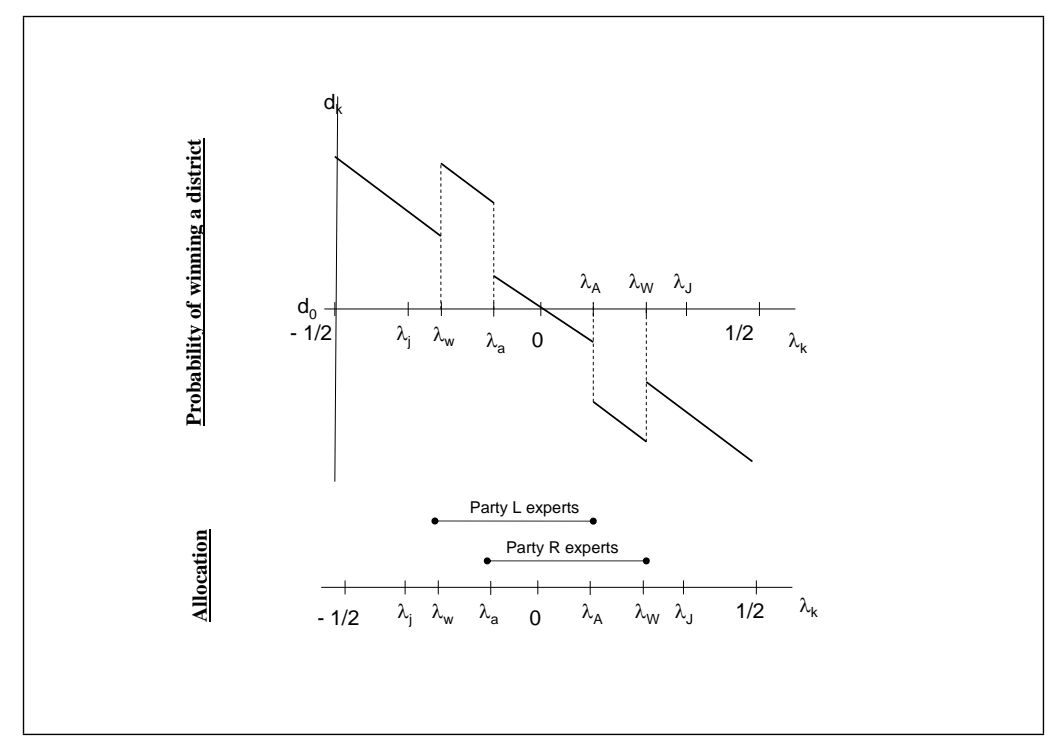


Figure 5: Allocation of experts and probability of winning if $\mu<\eta / 2$

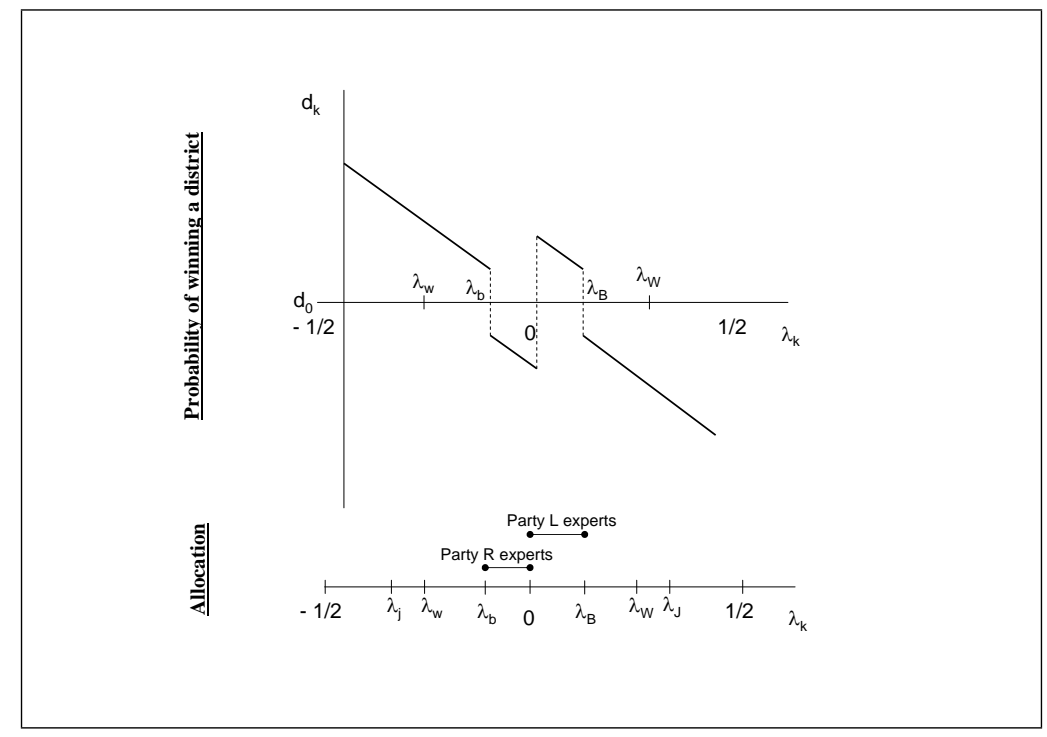


Figure 6: Convergence of demographic characteristics in close races
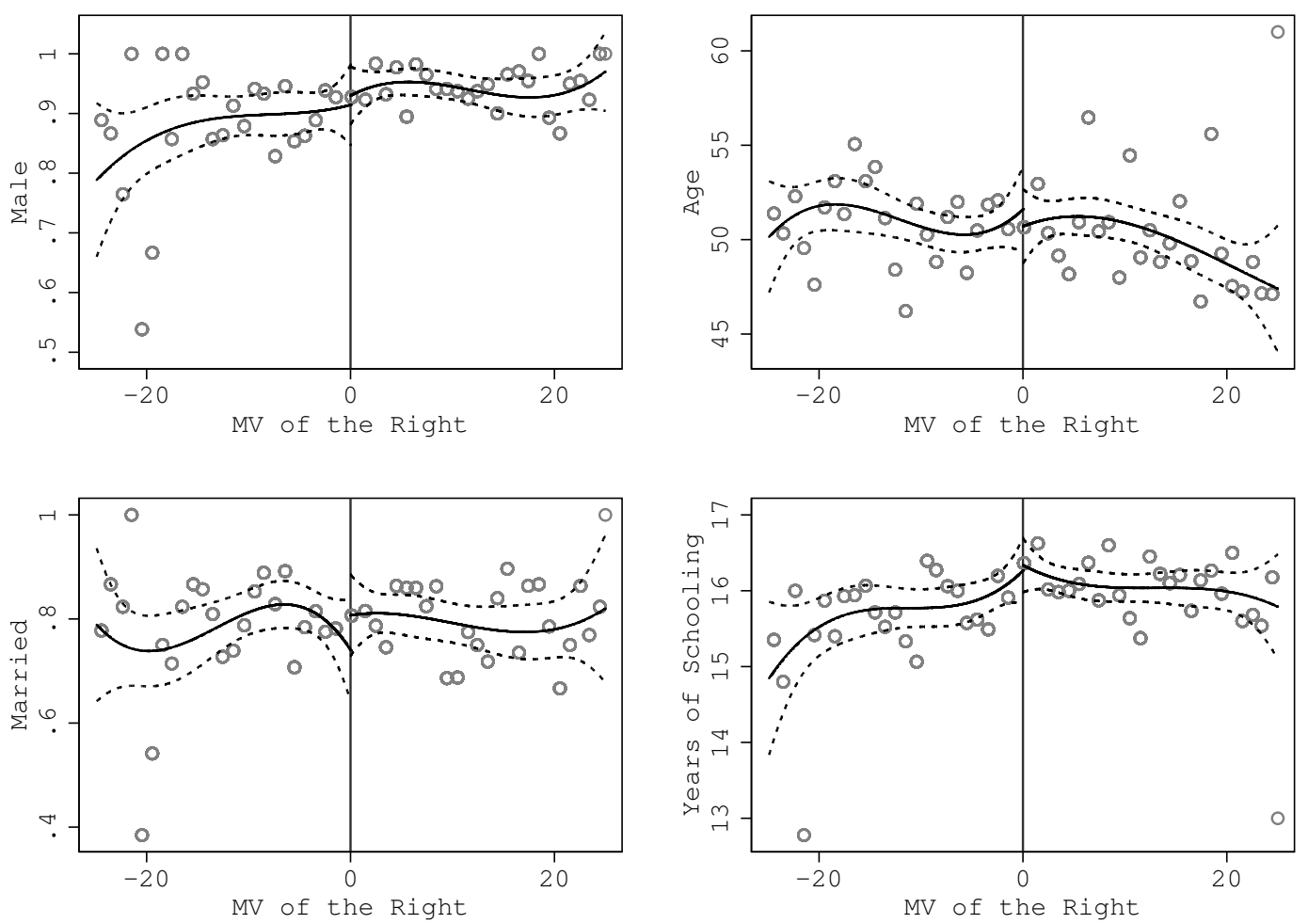

Notes. The solid line is a split $3^{r d}$-order polynomial in the margin of victory of the center-right coalition $(M V R)$, fitted over the interval $M V R \in[-25,+25]$; see also Table 7 . The dashed lines are the $95 \%$ confidence interval of the polynomial. Scatter points are averaged over 1-unit intervals; points to the left (right) of the vertical line at zero refer to left-wing (right-wing) politicians. Legislative terms XII, XIII, and XIV; 1,656 observations. 
Figure 7: Convergence of political experience in close races
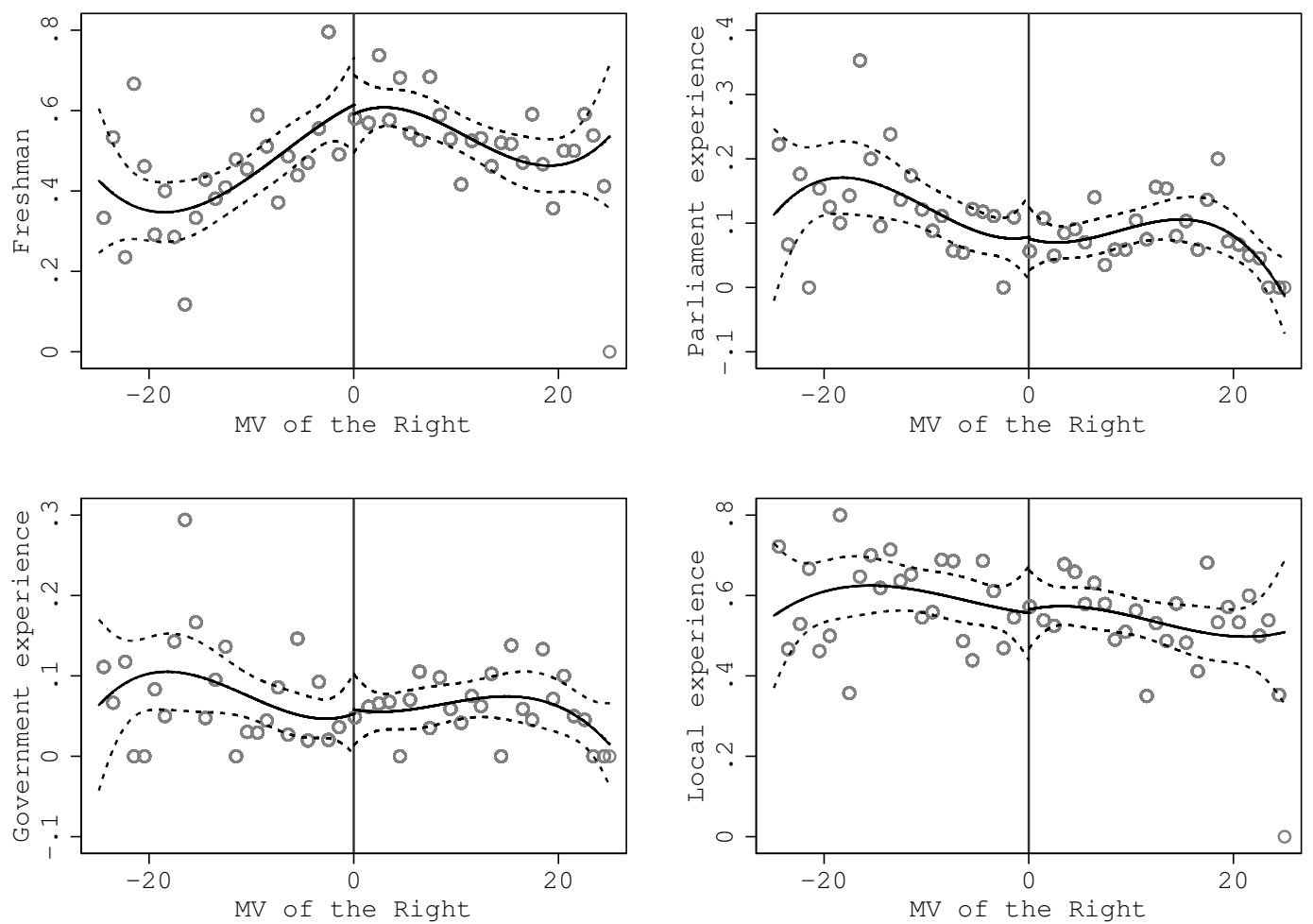

Notes. The solid line is a split $3^{r d}$-order polynomial in the margin of victory of the center-right coalition $(M V R)$, fitted over the interval $M V R \in[-25,+25]$; see also Table 7 . The dashed lines are the $95 \%$ confidence interval of the polynomial. Scatter points are averaged over 1-unit intervals; points to the left (right) of the vertical line at zero refer to left-wing (right-wing) politicians. Legislative terms XII, XIII, and XIV; 1,656 observations. 
Figure 8: Convergence of market experience in close races
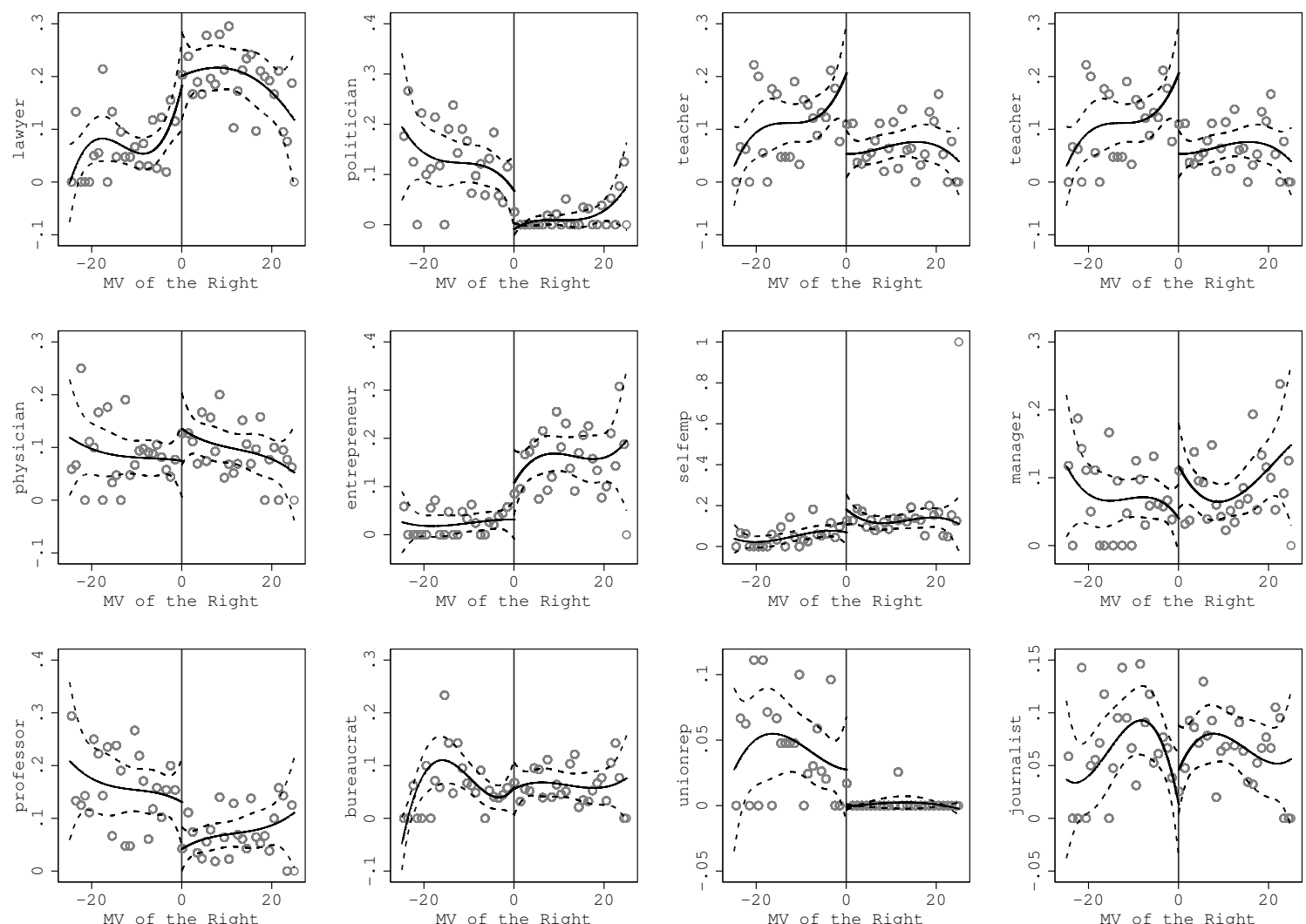

Notes. The solid line is a split $3^{\text {rd }}$-order polynomial in the margin of victory of the center-right coalition $(M V R)$, fitted over the interval $M V R \in[-25,+25]$; see also Table 7 . The dashed lines are the $95 \%$ confidence interval of the polynomial. Scatter points are averaged over 1-unit intervals; points to the left (right) of the vertical line at zero refer to left-wing (right-wing) politicians. Legislative terms XII, XIII, and XIV; 1,656 observations. 